\title{
Insular-Arc Volcanic Ecosystems as Centres of Forming the New Parts of Continental Biosphere (by the example of South-Kuril Insular Ridge)
}

\author{
Erland G. Kolomyts \\ Institute of Ecology of the Volga River Basin,Russian Academy of Sciences, 10 \\ Komzina str., Togliatti, 445003, Russia \\ egk2000@mail.ru
}

\begin{abstract}
The empirical statistical models of the island-arc stage of continental biosphere development in the North-West Pacific have been created by the example of regional bioclimatic system and experimental testsite near the active Mendeleev Volcano on the Kunashir Island (the South Kuril Ridge). The causal mechanisms of the known geographical phenomenon of insular extratropical Neo-Pacific, i.e., the general descent of the boundaries of altitudinal bioclimatic zones and the southward shift of natural zones on islands compared to the neighboring continents, are discussed. The phenomenal feature of bioclimatic system at the stage of insular landscape formation is the direct subordination of phytobiota to vertical hydrothermal gradients. It forms a system of future altitudinal zonality of the continent already within a frame-work of low-mountain island-arc landscape.It was shown that on this stage local geomorphological conditions created the centers of origin of diverse phytocoenological and soil structures of the higher (zonal-regional) levelat the initial stages of continental biosphere development.
\end{abstract}

An exceptionally important backbone role of forest phytobiota in the establishment and development of young volcanic landscapes was demonstrated. Theoptimizingstrategyprogramfor the development of plant communities, which is aimed at the maximum biomass formation on forest island-arc landscapes, is much more marked compared to their zonal analogs on the neighboring continent. At the same time, an exceptionally high percentage of green mass in the structure of production results in the acceleration of biological cycle as a factor of stability of forest community. All the above ensures the survival of insular ecosystems of the boreal Neo-Pacific under unfavorable conditions of "cold" oceanicity.

It was determined empirically that the structure and function oftopogeo(eco)systems in mobile belts of the planet are the sources of evolutionary global biosphere processes and driving forces of the biosphere evolution in whole.

Keywords: Pacific ocean mobile belt, regional bioclimatic system, altitudinal-expositional zo-nation,insular volcanic landscape,forest ecosystems, structure and functioning, empirical-statistical modeling.

\section{INTRODUCTION}

Kuril Ridge is the part of the Pacific Ocean oro-climatic mega ecotone of Northern Eurasia which covers the eastern, tectonically active margin of the continent and the insular land within the temperate and sub-Arctic geographic belts [44]. This transition zone is characterized by the submeridional extension of morphostructural belts of different ages and the marked latitudinal and longitudinal-sectoral differentiation of the climate. It is part of the global belt of convergence of matter-energy fluxes on the Earth surface: the so-called mobile belt of 
Insular-Arc Volcanic Ecosystems as Centres of Forming the New Parts of Continental Biosphere (by the example of South-Kuril Insular Ridge)

the planet [76]. The interaction between and transmutation of the two main types of geographical environment (oceanic and continental) in this "continental-oceanic suture zone" is extremely dynamic [23]; therefore, the insular, peninsular and littoral-continental territories (as well as the coupled shelf areas) are a natural laboratory for studying the modern geological stage of biosphere development, since this stage is most marked exactly in the Pacific mobile belt.

According to V. B. Sochava [84], island-ark territoryof Kuril Ridge includes in Cenozoic volcanogenic Neo-Pacific whichis replaced to the West by Sub-Pacific, i.e., the marginal continental geographical space of the Mesozoic geological age, and after that - by much more ancient (Paleozoic) Paleo-Pacificbeing part of the Siberian platform. Island-ark volcanic arcs are the initial stages of continental biosphere development, where centers of origin of diverse phytocoenological and landscape structures of continental type are created.

Pacific mega-ecotone of Northern Eurasia shows up one of sources of continental biosphere forming beginning in middle of Mesozoic [63]. Next processes created necessary conditions for that: (a) the frequently repeated joining and isolation of insular and marginal-continental land, which caused periodic isolation of biocoenotic complexes and interchange between them; it accelerated the evolutionary development of plant and animal populations and contributed to the diversity of their modern adaptations; and (b) intensive orogenesis and volcanism, which created the primary altitudinal differentiation of biota on the mountainous islands of the PacificOcean. Ecological niches remained permanently vacant, with the migration of modifications of biotic communities from the neighboring altitudinalzones. The primary altitudinal-zonal groupings of organisms and ecosystems were a basis of formation of the zonal types of geographic environment on the plains of all continents. These are some of the basic points of the concept of evolutionary biogeography put forward by D.V. Panfilov [66].

The problem of oceanicity and continentality has not yet been sufficiently developed for the eastern margin of the Asian continent, including the insular and peninsular territories going far into the water area of the Pacific Ocean and its marginal seas. For example, the causal mechanisms of two geographical phenomena of extratropical Neo Pacific: the general lowering of the boundaries of altitudinal climatic belts on the islands and the southward shift of natural zones compared to the neighboring continent, are still unclear $[37,38,58,90$, etc.]. The role of climatic parameters and heat balance structure per se in the formation of sharp biogeographical differences between the insular-arc Neo Pacific and the marginal-continental and continental-insular Sub Pacific has not been revealed either.

This presentation is aimed to elucidate some of the most substantial, in our opinion, peculiarities of spatial structure of the regional bioclimatic system of the Kuril Insular Arc (within the boreal belt), as well as to assess the creative role of this system at the insular-arc geological stage of evolution of the continental biosphere. The regional hydrometeorological data on the South Kuril Islandswere used for bioclimatic analysis. The empirical statistical models of the island-arc stage of continental biosphere development in the North-West Pacific have been created by the example of experimental testingsite in the vicinity of the active Mendeleev Volcano on the Kunashir Island (the South Kuril Ridge).Here (near by Yuzhno-Kurilsk weather station) in August, 1985 large-scape landscape-ecological survey was performed at experimental test site (Figure 1).

Staying for a long time under the conditions of monsoon-oceanic climate, the plant cover of the temperature belt on the island and marginal continental sectors of Pacific Mega ecotone of Northern Eurasia developed continuously [49]. The transition of flora and vegetation from the tertiary to quaternary period was relatively smooth, with migration of individual elements of the tertiary flora from north to south and back and with intrusion of representatives of the cold climate [48]. 
Insular-Arc Volcanic Ecosystems as Centres of Forming the New Parts of Continental Biosphere (by the example of South-Kuril Insular Ridge)

The processes of the primary subaerial biogenesis occurring at the Pacific Ring of Fire (the mobile belt of the Earth) are the successive stages of modern increment of the continental biosphere.The processes of formation of volcanogenic-accumulative morphosculpture created a lithogenic basis of the island-arc stage of establishment and development of the next part of the continental biosphere. All of the newly-formed terrestrial natural complexes in the oceanic mobile belts pass through this stage. Hence, the "Mendeleev Volcano" pilot test site on the Kunashir Island is undoubtedly representative for perceiving the initial stages of establishment and development of terrestrial geo(eco)systems in the surrounding oceanic environment.
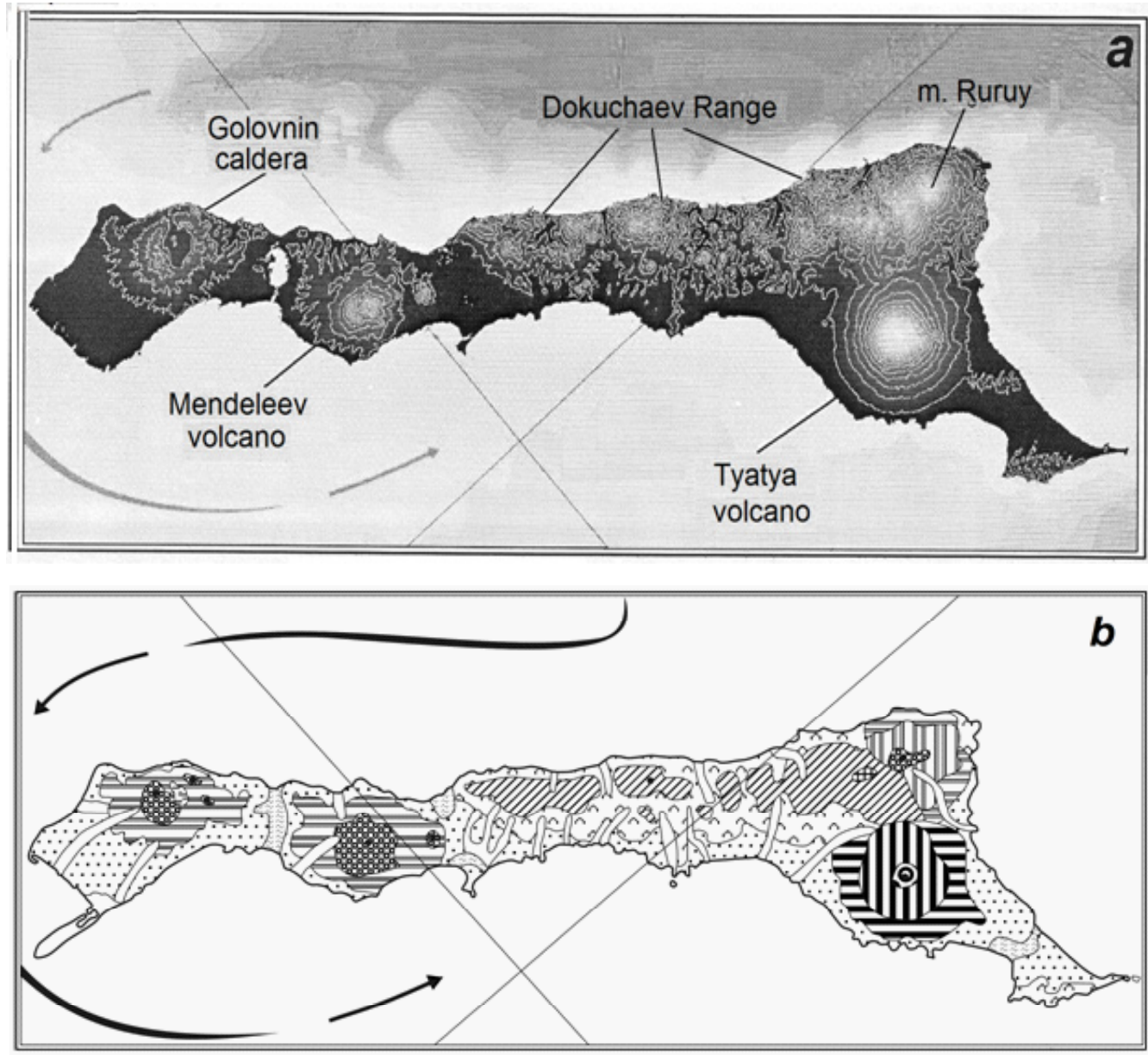

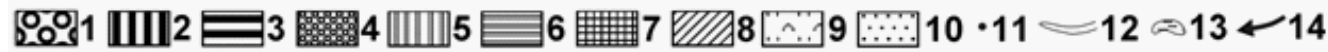

Fig1: Geomorphometry (a) and geomorphological (b) maps of the Kunashir Island.

Geomorphometry mapping was done by L.S. Sharaya. The legends to the geomorphological map, according to (Атлас ..., 2009): Mountain landscapes. Volcanic relief. Denudation-volcanic (weakly destroyed): 1 - the craters and steep upper parts of the cones; 2 - middle mountains, low mountains; 3 - lava-pyroclastic plains, baja-das (foothill trails). Denudation-volcanic (strongly destroyed): 4 - the craters and upper parts of the cones; 5 - middle mountains, low mountains; 6 - lava-pyroclastic plains, bajadas (foothill trails). Erosion-denudation relief (denudation-tectonic): 7 - middle mountains; 8 - low moun-tains, mid-altitude hill country; 9 - low-altitude hill country. Plain landscapes: 10 - Pleistocene abrasion-accumulative plains. Other designations: 11 - goltsy; 12 - river valleys; 13 - lakes; 14 - warm sea currents 
Insular-Arc Volcanic Ecosystems as Centres of Forming the New Parts of Continental Biosphere (by the example of South-Kuril Insular Ridge)

\section{VOLCANOGENIC BASIS OF THE INSULAR-ARC LANDSCAPES}

\section{Morphotectonics of the Kuril Island Arc}

The Kuril Islands are included into the system of island arcs of the Pacific Ocean Mobile Belt. They are the above-water part of epigeosynclinal mountain ranges separating the kettle of the marginal Sea of Okhotsk from the Kuril-Kamchatka Trench in the Pacific Ocean. The island-arc systems are the zones of formation of the major geochemical reservoirs of our planet; therefore, they play the key role in plate tectonics [59], which creates the shape of continents. This very fact predetermines the representativeness of island-arc volcanic landscapes as objects for studying the initial stages of formation of the continental biosphere and disclosure of the initial mechanisms of subaerial landscape genesis.

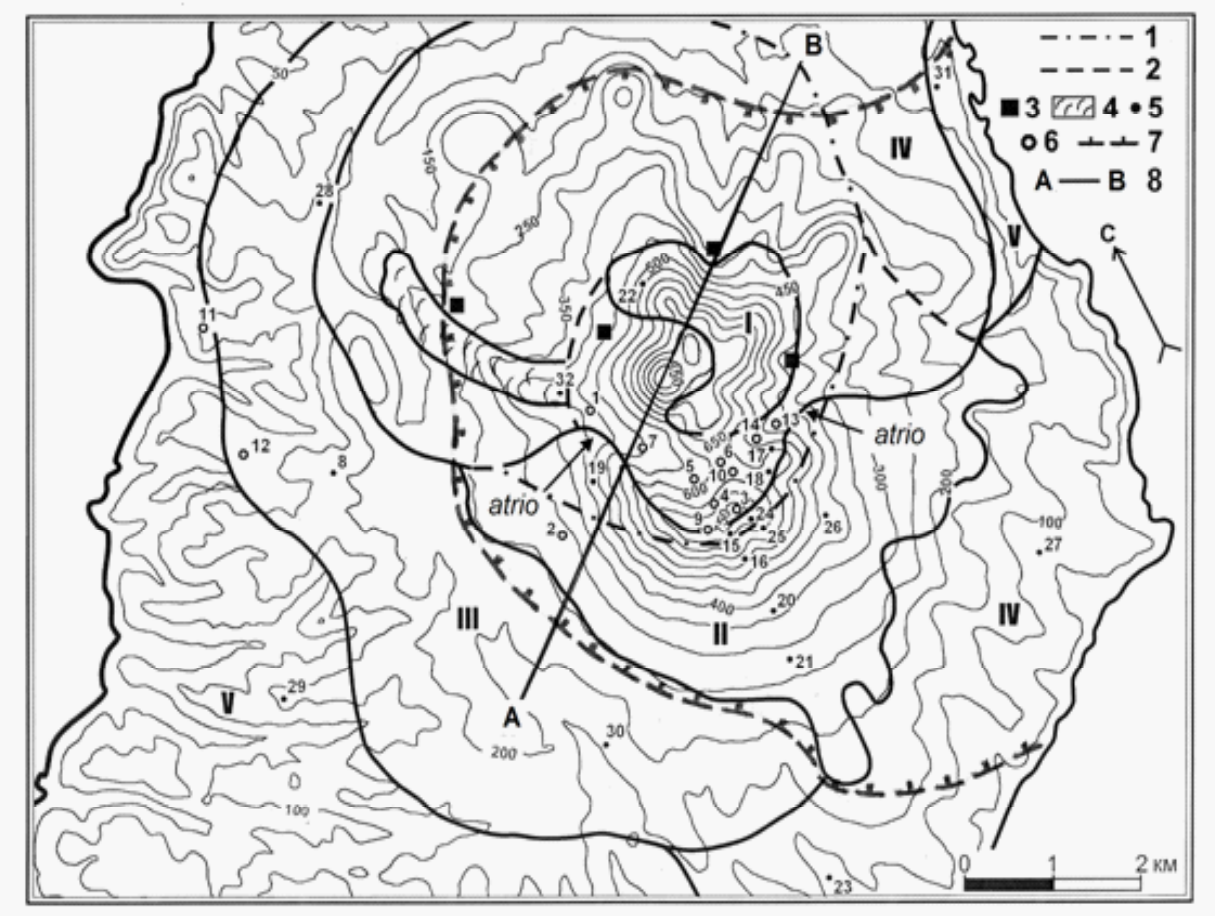

Fig2. The hypsometric map of the Mendeleev Volcano and its surroundings (by L.S. Sharaya), with indication of the boundaries of the main geological structures and solfatare fields, as well as the test grounds of landscape ecological survey.

Geological structures, according to [27]: I - central cone; II - second somma; III - first som-ma; IV - nonsegmented mass (partly tertiary); $\mathrm{V}$ - foundation (tertiary terrigenic-pyroclastic rocks). Other designations: 1 - the outlines of ancient caldera; 2 - the outlines of young caldera; 3 - solfatare fields; 4 - pyroclastic flow; 5 - test grounds; 6 - test grounds with temperature anomalies in soil; 7 - the boundaries of geothermal fields of the volcanic cone, according to Sa-fonov et al., 1998); 8 - the line of seismic profiling (see below Fig. 5).

$23,30,21, \ldots$ - the numbers of sample plots (points).

According to the modern concepts [7], the Kuril Island Arc is a system of volcanic belts of different age, which are situated above the zones of subduction - the V-shaped underthrusting of oceanic crust beneath continental crust. Volcanoes form on large magmatic columns, or diapires, which rise in the asthenosphere in regular rows 
Insular-Arc Volcanic Ecosystems as Centres of Forming the New Parts of Continental Biosphere (by the example of South-Kuril Insular Ridge)

by means of gravitational convection (buoying). On the Kuril Islands, there are 104 active volcanoes, apart from submarine volcanoes; 39 of them are active [5]. The effect of volcanism on the natural-territorial complexes of the island is directly proportional to the area and volume of volcanic bodies. Volcanic cones and adjacent lava and pyroclastic plains make up to $90 \%$ of the area and volume of all Kuril volcanic landscapes [28]. The percentage of volcanic landscapes of the island area is as follows: Iturup - 35; Urup - 66; Simushir - 44; Shikotan - 79; Onekotan - 90; Paramushir - 28.

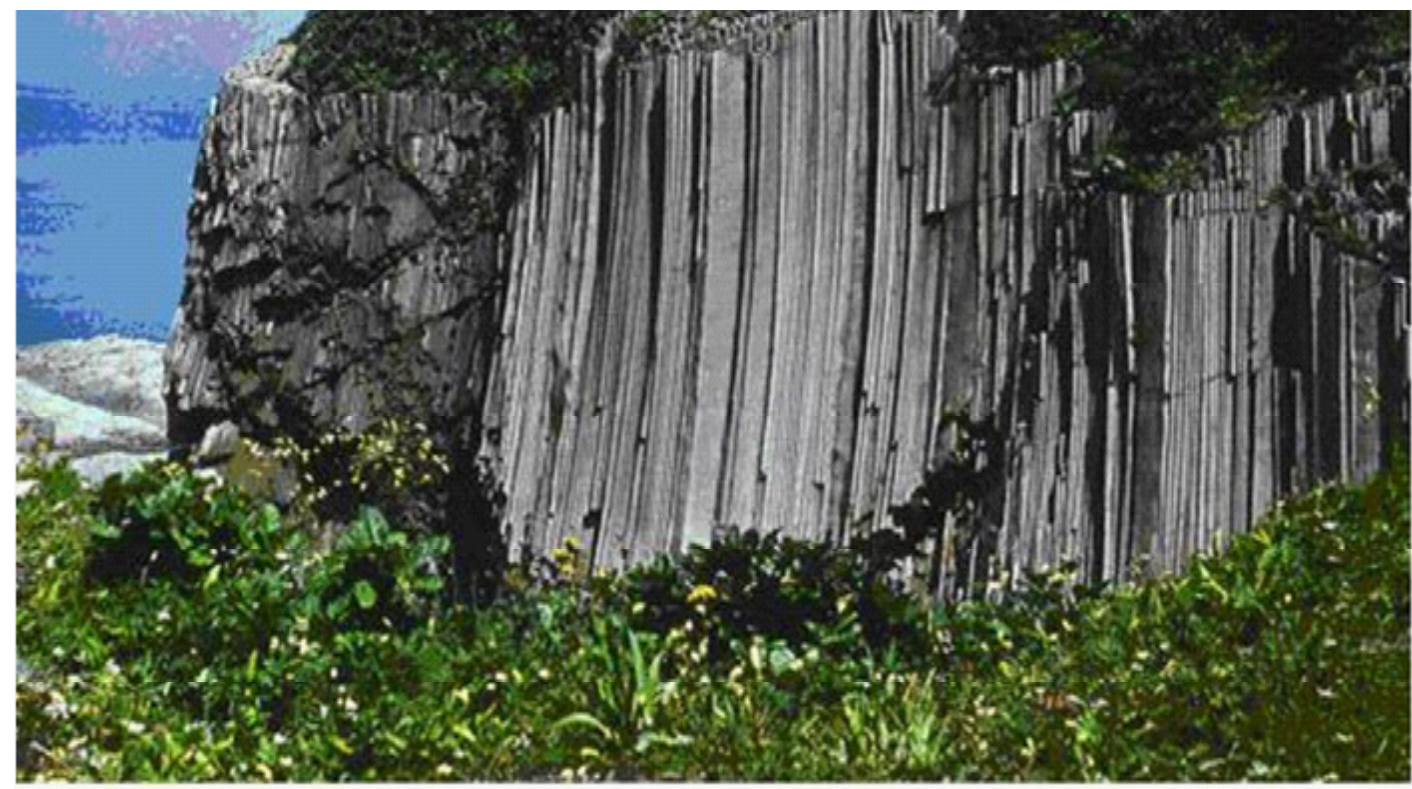

Fig3. The Kunashir Island. Andesitic-basaltic lava outcrops on the marine ter-race. Below: Kuril bamboo thickets; above: the low-growing cedar elfin wood cover descending to the sea.

The present-day relief of the Kunashir Island is a chain of large and small volcanoes of different age (from middle-Pleistocene to present-day) connected with abrasion-accumulative lowland-plain vents. These vents emerged in the Late Holocene: 2200-2300 years ago [75]. Geomorphometric processing of the satellite image of the Kunashir Island by L.S. Sharaya showed (Fig. $4.1 \mathrm{a}$ ) that this island was formed by the linear-nested arrangement of volcanoes typical of the Greater Kuril Ridge [27] on the basis of at least nine volcanic cones of different age (from Early Pleistocene to present-day) and, accordingly, different levels of activity. The most ancient volcanic cones compose the Dokuchayev Range, which is unreasonably indicated on the geomorphological map (Fig. $4.1 \mathrm{~b}$ ) as an erosion-denudation (denudation-tectonic) relief, without any allusion to its originally volcanogenic genesis. Low-lying isthmuses combine the volcanic cones into a single island system of Kunashir.

Thus, in the mobile belt of the planet, volcanoes are the foci of accretion of the continental biosphere. The lithogenic basis of young island-arc landscapes is directly related to the deep endogenous processes in the "living planet" Earth, which determines the direct landscape-forming influence of the morphotectonic factor [28]. The extremely high frequency and intensity of eruptions and tempos of relief formation (on the geological time scale) cause an exceptionally complete correspondence between the forms of the earth's surface and the geological structure [13]. Periodic recurrence of volcanic activity may bring to naught the results of denudation processes closely associated with the landscape formation.

The poorly developed denudation processes in the regions of present-day volcanism, as has already been said, are due to mainly tectonic downwarping (or delayed uplift) of these areas compared to the 
Insular-Arc Volcanic Ecosystems as Centres of Forming the New Parts of Continental Biosphere (by the example of South-Kuril Insular Ridge)

neighboring territories. Under such morphotectonic conditions, the destruction and ablation of bedrock layers proceed slowly, while the development of denudation-accumulative exogenous is considerably suppressed - largely due to the poorly developed river network of the territory. Hence, the predetermining role of volcanogenic-accumulative morphosculpture in landscape structure is much more marked.

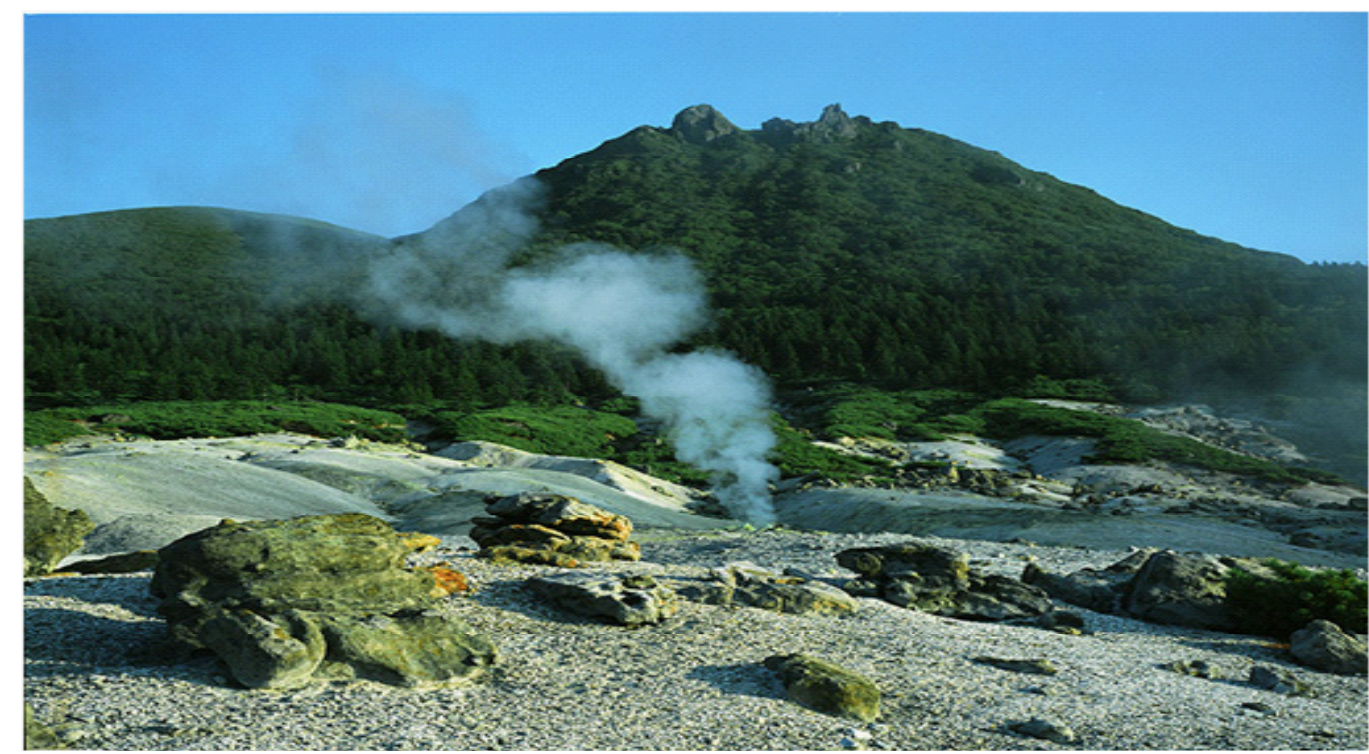

Fig4. The solfatare field on the northeastern slope of the Mendeleev Volcano. In the back-ground: the band of stone birch/spruce forest changing above into the belt of cedar elfin wood.

One should also add the considerable resistance of lava rock masses to wash-out, as well as the high water permeability of loose pyroclastic material, which prevents the formation of water-bearing strata in the upper layers of mother rock and, consequently, a stable channel runoff. As a result of rapid infiltration of precipitations, the surface water runoff ceases even on steep volcanic slopes, and the development of an accumulative-humus soil layer on ashfalls slows down the erosion and the formation of fluvial relief [62]. The slopes of the Mendeleev Volcano are almost devoid of watercourses, while the great diversity of genetic types of lakes on the Kunashir Island [45] are known to indicate the disconnection of catchment basins, the very poorly developed hydrological network of the territory.

\section{The Mendeleev Volcano}

The Mendeleev Volcano (true altitude $890 \mathrm{~m}$ ) coincides with the longitudinal fault along the crests of the inner ridge of the Kuril geosynclinal system [12]. It is among $27 \%$ of all active single volcanoes on the Kuril Islands and has a structure of the Somma-Vesuvius type, which is most representative of an island arc [26], i.e., belongs to extrusive volcanoes (see on the front cover of given book) or, more precisely, to the type of active "clustered" (multi-vent) isolated stratovolcanoes [60,97]. A rather large cone (up to $12 \mathrm{~km}$ in diameter) appeared on the tertiary foundation [5]. At the beginning of formation of the volcano, andesites and andesitobasalts were poured out but, gradually, the rocks became more and more acidic, and the final stage was characterized by explosions and ejections of acidic pumices [27].

The acidic volcanism, which developed in the middle of Late Pleistocene interstadial, brought a new pumice cover on the island. The washed-up pyroclastic material of this stage became part of the deposits of an 80-85-m marine terrace [13]. On the coast, this terrace forms steep rocky cliffs with hexagonal columns of quartz andesite (see above Fig. 3). 
Insular-Arc Volcanic Ecosystems as Centres of Forming the New Parts of Continental Biosphere (by the example of South-Kuril Insular Ridge)

The total terrain of the ecoregion has a distinct NW $\leftrightarrow$ SE asymmetry. The Pacific pedestal of the volcano is narrower and steeper, with narrow marine terraces and short deeply cut valleys of small streams. Here and there, the lava tongues of late eruptions are laid over the surface of marine terraces [45]. The Sea-of-Okhotsk pedestal, on the contrary, is more gentle and broader; in the foreland, it is deeply cut with a well-developed river network, with turf-covered creek valleys and sea cliffs. Thus, the Sea-of-Okhotsk submontane sector of the southern part of Kunashir has a much more developed river network compared to the Pacific Ocean sector. It may be supposed that the landscapes of the Sea-of-Okhotsk sector of the southern part of Kunashir have a more ancient foundation and the longer development pathway compared to the landscapes of the Pacific sector.

The Mendeleev stratovolcano is set on a system of faults, normal faults and fracture zones of the Earth's crust determining the high magma permeability of the latter. The three successively formed volcanic cones were later destroyed as a result of explosive eruptions with the formation of caldera-crater depressions of $6 \times 9,3 \times 3.5$ and $1 \times 1 \mathrm{~km}$ in size [47]. The age of the most ancient caldera is about 40000 years [13]. The formation of the last caldera-crater depression about 2500 years ago was followed by the growth of an andesitic-dacitic extrusive dome (Abdurakhmanov et al., 2004).

The volcano is composed of two somas of different age (the annular crests with outer slopes) and a central cone, which is complicated by strong destruction of its separate parts and the presence of collateral formations [26]. The most ancient volcanic formation (of the preglacial period) is a large caldera (a vast depression on the volcano top) of 6-7 km in diameter, with its strongly destroyed ridge remaining only in the northwest. The formation of caldera was accompanied by the formation of the first somma cloak, i.e., loose pyroclastic strata of the Golovnin Formation, according to E.K. Markhinin [56]. This somma currently encircles the lower parts of the SW-W-NW slopes of the Mendeleev Volcano and partially covers the piedmont plains of its Pacific sector (Fig. 4.2).

In the epoch of the Late Pleistocene (Würm) interstadial, i.e., about 39000-40000 years ago, according to [13, 27], a new cone of no less than 6-8 km in size appeared at the southern edge of the first caldera, which in its northern part was destroyed by directed blast. The second caldera (3-3.5 km in diameter) was formed, and the synchronous second somma on the S-SE-E slopes of the volcano (from the tops to the true altitudes of 150-200 $\mathrm{m}$ ) overlaid the first somma. Here, the crest of the second caldera remained as a small semicircular ridge, (see Fig. 2), with a plateau-like type of the Mechnikov Mountain (the highest point is $798 \mathrm{~m}$ of true altitude). The most of our test grounds were situated on the slopes of this somma (down to its foothills, with access to the coastal marine terraces), as well as in the atrio - a semicircular depression separating the somma from the central dome (see Fig. 2). The northern half of the second somma partially filled the first caldera, while the position of the second caldera is fixed by the four major solfatares - fumarole fields. The presence of caldera indicates the existence of a large hollow magmatic focus under the volcano [67], while fumaroles are indicators of the presence of productive geothermal reservoirs in the depths of the volcanic dome [18]. The Northeastern and Northwestern fumarole fields (solfatares) and most active; there, magmatic energy is discharged not only by releasing volcanic gases and thermal solutions but also as periodical microquakes (with a focus no less than $20 \mathrm{~km}$ deep).

Volcano is considered active if the quiescent stage in its eruptive history is no longer than 3200-3500 years [61]. Consequently, the Mendeleev Volcano is one of the currently active volcanoes. The last stage in volcanic development was the formation of blasting cones [explosion craters along the ring faults in the periphery of the extrusive dome, resulting in the formation of active fumarole fields with gas and hot water $\left(90-110^{\circ} \mathrm{C}\right)$ vents on the N, NW and NS slopes of the volcano. There are four well-marked explosive craters set on the ellipsoidal trajectory of the fault, which outlines the entire eruptive system of the Mendeleev Volcano [57]. The main present-day fumarole activity of the volcano shows itself in these four blasting cones, as well as in the crater of the central cone (Fig. 4). 
Insular-Arc Volcanic Ecosystems as Centres of Forming the New Parts of Continental Biosphere (by the example of South-Kuril Insular Ridge)

The latest (pyroclastic) eruption of the Mendeleev Volcano occurred in 1880 [31], and its steam and gas activity was observed in 1901, 1946 and 1977. The current state of the volcano figuratively called "the Sleeping Beauty" by people, with reference to volcanic landscape itself, will be denoted as a passively active state and its fumarole activity will be denoted as a manifestation of passive magmatic energy. The intensive gas-hydrothermal activity of the volcano began to develop exactly at the final Late Quaternary (andesitic) stage of its history [17] and, thus, characterizes its passive active state.

The fumarole activity is caused by the high fluid conductance of volcanic-tectonic zone at the final stage of its progressive development, when fluid mass transfer becomes a self-organizing system [53]. Due to the intrusion of fluid from the subducted oceanic platform into the mantle wedge, the typical island-arc magmas are melted in the high temperature zone. The most of hydrous minerals are dehydrated under the frontal zone, and the aqueous fluid migrates upward, directly into the zone of magma formation in the mantle wedge (Avdeyko et al., 2001). It is just the beginning of formation of volcanic hydrotherms.

The steam and gas vents are often situated linearly, thereby accentuating their confinement to fracture systems [57]. The IR thermal imaging of the northeastern fumarole field of the Mendeleev Volcano in 2010 showed the outlines of the most heated regions over the entire field [47]. Altogether, 180 thermograms were obtained for the volcano, with detailed representation of the temperatures at the sites of the northeastern slope of this extrusive dome.

The internal structure of the volcano is a system of near-surface and deep magmatic foci (Fig. 5 and 6). The major peripheral focus of $\sim 2 \mathrm{~km}$ in diameter is situated directly under the volcano at a depth of $4.5 \mathrm{~km}$; the deep magmatic focus is located at an altitude of 30-60 km. The upper lava complex of the ancient somma (I, see Fig. 2) is formed by andesitic flows with subordinate pyroclastics [57]. The basic composition of lavas is quartz dacite with olivine. The underlying part of the volcanic cone with predominant area is represented by the upper effusive andesitic complex (II). The volcano bottom is outlined with an intermediate pyroclastic complex (III) consisting of tuffs, tuff conglomerates, and coarse pyroclastics. When reaching the coastal plain areas, these formations intermingle with thesea-washed terrigenous deposits and create a terraced erosion-accumulative complex.

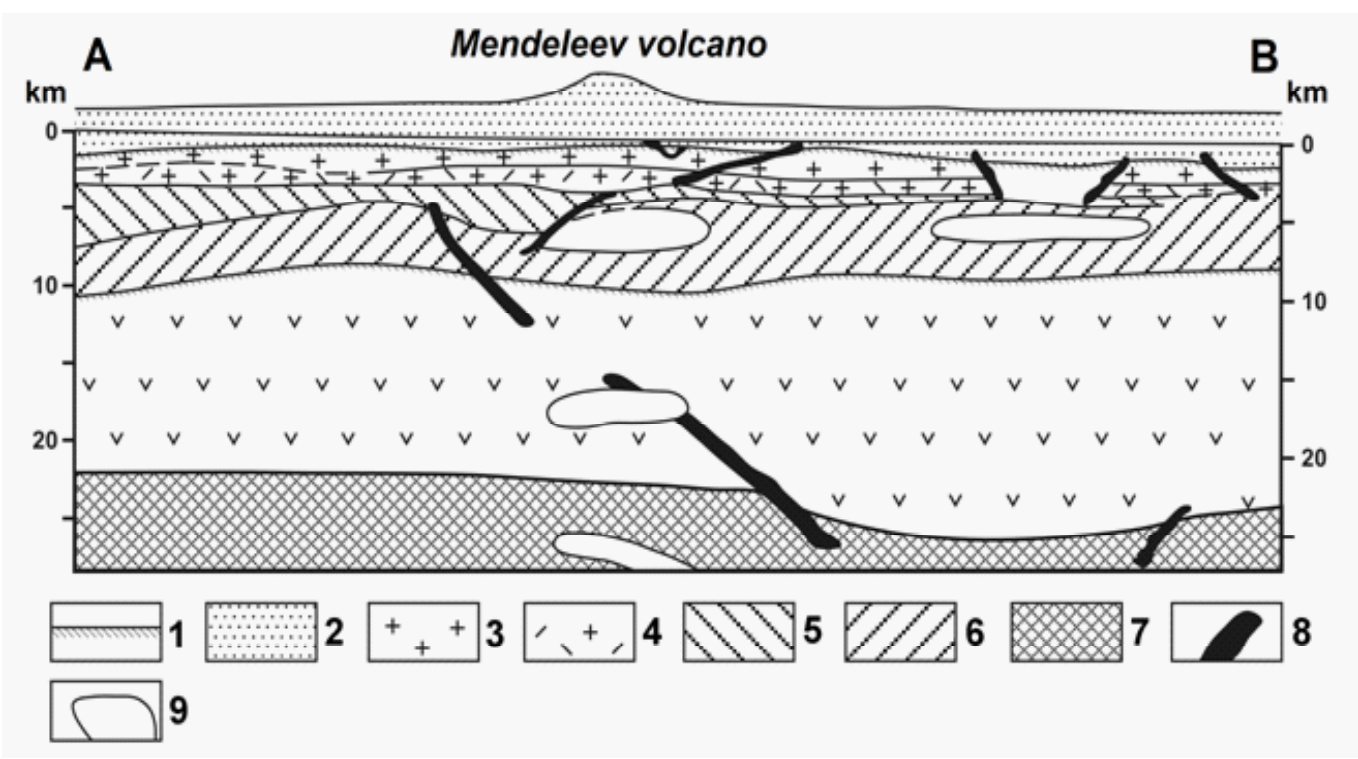

Fig5. The depth profile of the lithosphere across the Mendeleev Volcano by the AB profile 
Insular-Arc Volcanic Ecosystems as Centres of Forming the New Parts of Continental Biosphere (by the example of South-Kuril Insular Ridge)

(see Fig. 2), according to [97].1 - the roof of the basaltic layer; 2 - the volcanogenic sediment layers; 3 and 4 - the upper and lower parts of the granite-gneiss layer; 5 and 6 - the upper and lower parts of the granulite-gneiss layer; 8 - the basaltic layer; 9 - the areas of melting of the lithosphere.

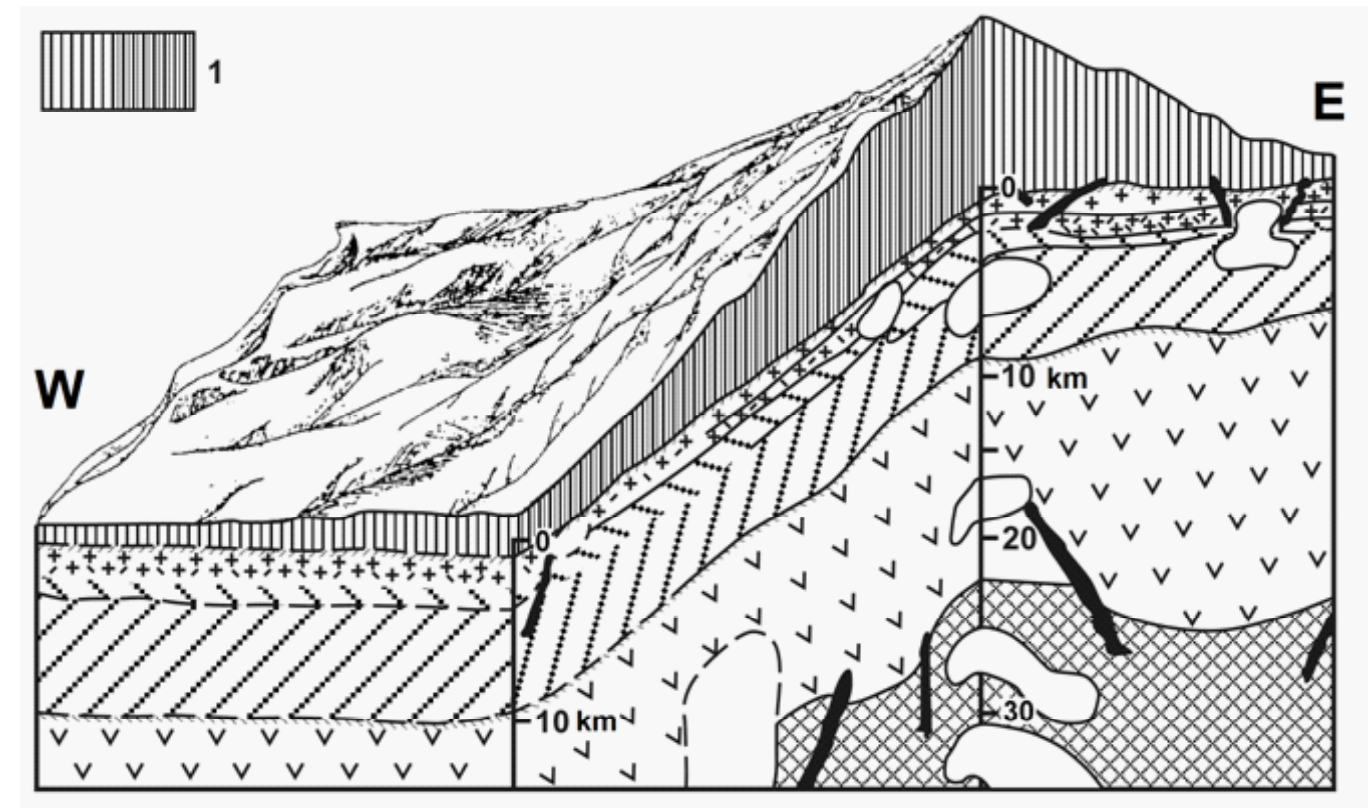

Fig6. The 3D model of the lithospheric structure under the Mendeleev Volcano

according to [97]. 1 - the volcanogenic sediment layers. Other symbols are as in Fig. 5.

Since the entire volcanic massif is sheared closer to the Pacific Ocean coast, the Sea-of-Okhotsk sector of the submontane morphostructural belt is more gentle and extended, with a much more developed river network [45]. Finally, along the Pacific Ocean coast there is a narrow band of the lower effusive complex (IV) formed by andesitic-basaltic lava flows up to $8 \mathrm{~m}$ thick, which underlie the Middle Pleistocene marine deposits and are exposed in sea cliffs (see Fig. 3).

The fumarole fields are known [18] to be the objects of thermal discharge of the steam-and-gas and magmatic activities of the volcano and are connected with productive geothermal reservoirs. Let us note this important circumstance exerting, as we will see below, a substantial effect on soil temperatures and causing the respective structural and functional changes in the soil-plant cover of young volcanic landscape.

At present, the active volcano on the Kunashir Island is only the known Tyatya Volcano. Its last large-scale eruption was in 1973. However, the solfatares of even currently inactive Kuril volcanoes, like the Mendeleev Volcano, carry up approximately the same amounts of juvenile water and other steam-and-gas magma components per year as those that are released in explosions during eruptions [57]. The hot springs at the bottom of the Mendeleev Volcano with a temperature of 30-60 and more are connected with the circulation of deep thermal waters. Jarosites and geyserites are formed along their flow paths, each covering an area of about $3000 \mathrm{~m}^{2}$.

\section{RESEARCH OBJECTS AT THE EXPERIMMENT TEST Site}

Geomorphology of the Mendeleev volcano landscape is characterized by the following two features: (1) vertical landscape microstratification, including a certain level of true altitudes and the predominant type of mesolocation, and (2) macro exposure of volcanic slopes and surrounding plains. The four landscape microlayers 
Insular-Arc Volcanic Ecosystems as Centres of Forming the New Parts of Continental Biosphere (by the example of South-Kuril Insular Ridge)

were distinguished: piedmont plain (below 230-250 m) and the lower (230-550 m), middle (500-720 m) and upper (above 670-720 m) low-mountain layers. Due to a rather simple geometric configuration of volcanic cone itself, the above altitudinal microlayers correspond to the four types of mesolocations, according to [25, 71]: accumulative (A), transaccumulative (TA), transient (T) and transeluvial (TE). In accordance with the regional climatic contrasts determined by the circulation exposition of macroslopes of the South Kuril Islands [43], the first three landscape layers were divided into two parts (sectors): the Okhotsk Sea (the SZ-W-NW-N exposure sector) and the Pacific Ocean (the NE-E-SE-S sector).

At the same time the certain forms o microrelief (minor surface landform) have been distinguished - by the degree of their dissipating or on the contrary accumulating influence on water and ground masses. This catenary system includes seven geotops - forms of microrelief: (1) $\chi$-crests with even and bulging longitudinal profile; (2) $千$ - terrace ledges with even diametrical profile; (3) $\approx$ - saddles and ridges with longitudinal profile; (4) $\nsucc$ - flat parts of slopes; (5) $\nsucc$ - bottoms of hollow and river valleys; (6) $\downarrow$ - foot of terrace and crests; (7) $\nsucc$ - half-close arm-chair-shape accumulative forms. Fist four geotops correspond to eluvial and transeluvial types of sites, and rest ones - to types TA, A and Saq.

The South Kurils, particularly the Kunashir Island, are an example of high diversity of vegetation types of the temperate belt [55, 70, 72]. According to the latest botanical-geographical demarcation [46], the Kunashir Island has been included into the South Kuril-Hokkaido district and the South Kuril region, with predominance of dark-coniferous/bro-adleaf forests enriched in southern east-Asian subtropical elements: Magnolia hypoleuca, Quercus crispula, Q. dentate, Kalopanax septemlobus,Acer tschonoskii, A. japonicum, Betula maximowicziana, Daphniphyllum humile,Aralia cordata(Figs7 and 8). Thus, the region of our experimental test site on the Mendeleev Volcano, with reference to plant cover, is most similar to the neighboring Hokkaido Island: about $78 \%$ species in common with the latter (54\% with Sakhalin and 44\% with Priamurye).

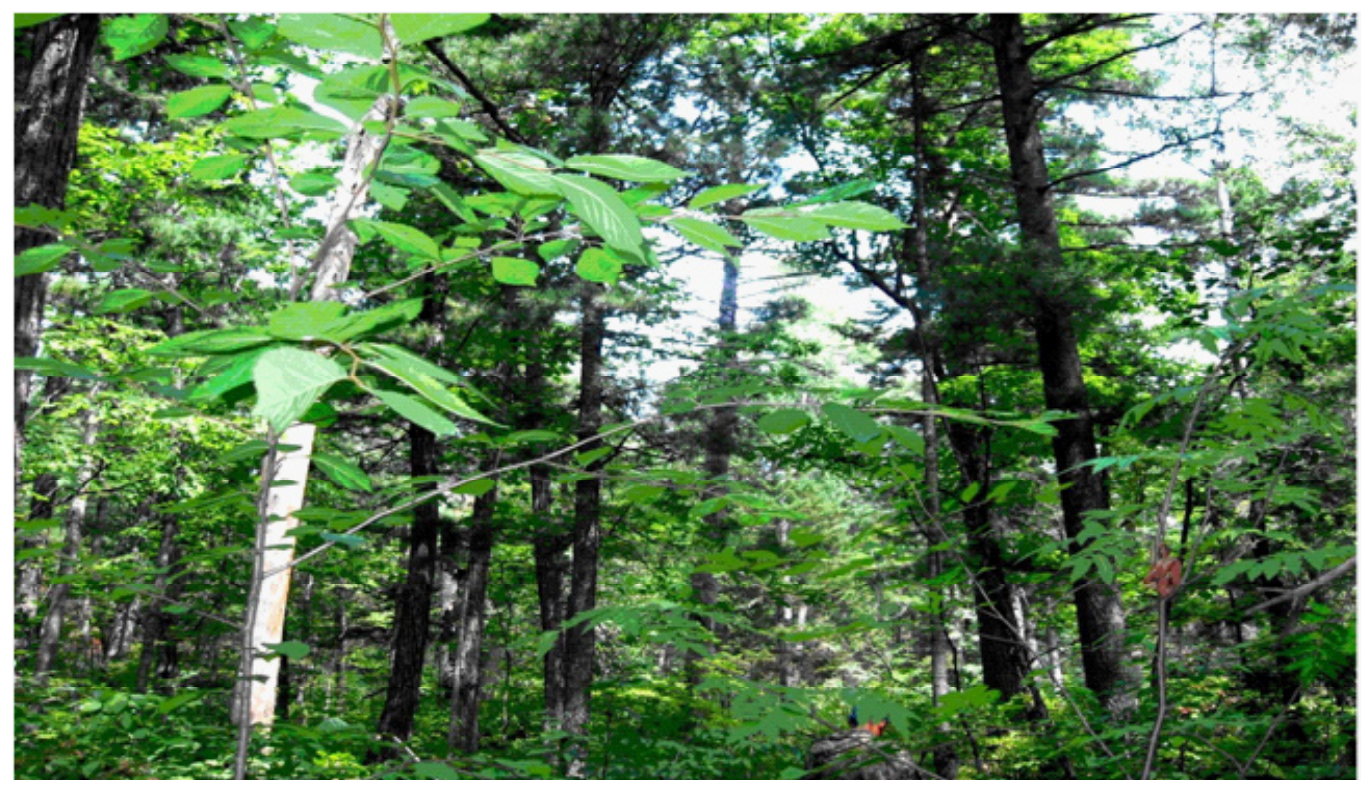

Fig7. The mixed dark-coniferous/broadleaf forest in the piedmont zone of the Mendeleev volca-no landscape.

Here, we have distinguished six groups of forest types (the symbols and taxonomic norms of true altitudes are given in parentheses):(1) mixed dark-coniferous/broadleaf forests ( $\boldsymbol{\uparrow}$ - CB; 184 m; see Fig. 7 ); (2) dark-coniferous (spruce/fir) forests (林 - DC; 379 m; Fig.9); (3) buffer stone birch/spruce forests (んૂイ-SbS; 575 m); (4) stone birch elfin woodland with cedar elfin wood ( $\boldsymbol{3}$ - SbCe; 685 m); (5) cedar elfin 
Insular-Arc Volcanic Ecosystems as Centres of Forming the New Parts of Continental Biosphere (by the example of South-Kuril Insular Ridge)

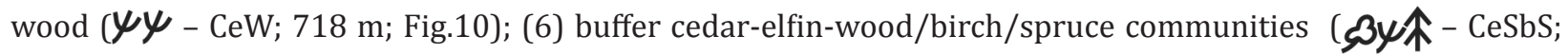
$575 \mathrm{~m}$ ).These types belong to the respective floristic phratries: (1) - to Manchurian-Okhotsk (MO); (2) and (3) - to Okhotsk (Okh); (4) - to Beringian-Kamchatka (BK); (5) - to Beringian (Ber); (6) - to BeringianKamchatka-Okhotsk (BKO).

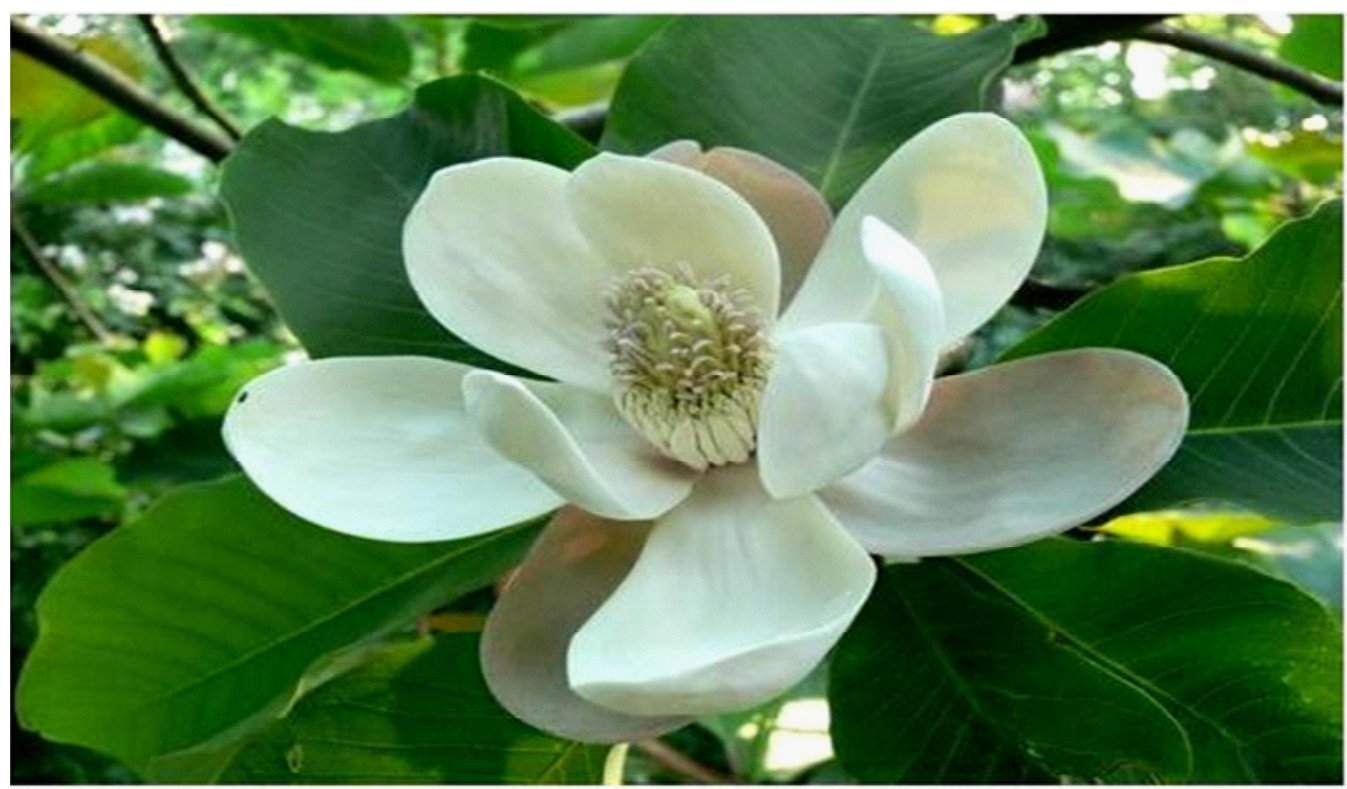

Fig8. Magnolia (Magnolia abovata) - the subtropical relict in South-Kuril boreal forests.

At modeling, the high emphasis was placed on phytocoenotyic functional block - the parameters of annual and perennial cycles of plant matter turnover.The values of the live and dead phytomasses and productivity were measured and calculated as discrete parameters of autotrophic biogenesis, byterminology [25], as the ascendant branch of forest functioning. Let us enumerate these parameters, with indication of their designation.

1. Phytomass, tons/ha: (a) total live above-ground phytomass $(B L)$; (b) total dead above-ground phytomass - brushwood, deadwood and forest litter mass ( $B D)$; (c) separately forest litter mass $(M L)$.

2. Productivity, tons/ha per year: (a) annual growth of tree and shrub skeletal phytomass of $\left(P S_{\text {tr-shr }}\right)$; (b) annual production of tree and shrub green mass $\left(P V_{\text {tr-shr }}\right)$; (c) production of grass stand green mass $(P G)$; $(\mathrm{d})$ total annual production of green mass $\left(P V_{\mathrm{tot}}\right)$; (e) summary annual production of trees and shrubs $\left(P C_{\mathrm{tr}-\mathrm{shr}}\right)$; $(\mathrm{g})$ total annual production of forest phytocoenosis $\left(P C_{\text {tot }}\right)$.

3. Complex indices of autotrophic biogenesis were calculated: (a) the coefficient of annual above-ground phytomass turnover - the ratio of summary green mass production to the total above ground live phytomass $\left(C R=P V_{\text {tot }} / B L\right)$; (b) the allometric coefficient $\left(C A=\log \left(P V_{\text {tot }}\right) / \log (B L)\right.$; (c) coefficient of annual destruction - the ratio of a forest litter mass $(M L)$ to a mass of green substance produced annually, ( $C Y=M L / P V_{\text {tot }^{\prime}}$ years).

According to the concept of bioenergetics of ecosystem development [65], the ratio productivity to biomass can be considered as a functional index of maturity of forest community. Bioproduction is largely a landscape-geophysical process [14], while the $P V_{\text {tot }} / B L$ ratio can be considered also as a coefficient of ecological efficiency of phytocoenosis. The higher values of this parameter correspond to the greater amounts of plant matter produced at the same initial phytomass. 
Insular-Arc Volcanic Ecosystems as Centres of Forming the New Parts of Continental Biosphere (by the example of South-Kuril Insular Ridge)

The value of $C A$ parameter was assessed in terms of the known principle of optimality, which is expressed by allometric law $[32,76]$. According to the latter, there is a certain constant value of this for each of the zonal types of landscapes, in spite of the significant fluctuations of productivity and biomass within this type [68]. On the zonal-regional scale (for flat interfluve types of location), this coefficient monotonously increases from 0.53-0.54 in forest-tundra and northern taiga to $0.60-0.62$ in the broad-leaved forests of plains and mountains and then more abruptly increases to $0.84-0.88$ at transition to meadow and then dry steppe of the subboreal belt. Along with the above, each zonal subdivision of geographical environment has the $C A$ values which are higher than in flat interfluves and correspond to plant communities of more humid habitats.

Coefficient $C Y$ is also known as the litter-fall index [9], which is expressed as the period (in years) necessary for the accumulation of a given mass of forest litter (dead plants) at the existing annual rates of plant mortality and organic matter decomposition.

\section{CAlCulations of Regional Hydrothermal PARAMETERS}

The true altitude distribution of the monthly average temperature of the warmest month (August) $t_{\mathrm{VIII}}$ and the annual precipitation $r_{\mathrm{yr}}$ for the Sea-of-Okhotsk and Pacific Ocean sectors of the Mendeleev Volcano (see below Figure8) was calculated by L.S. Sharaya on the basis of WorldClim data [33] using the Analytical GIS Eco software [95]. The WorldClim planetary matrices were formed by interpolation of meteorological data. The Thin Plate Smoothing Spline Interpolation implemented in the ANUSPLIN software package was used [34]. The interpolation procedure for land was performed with the latitude, longitude and altitude used as independent variables. For the South Kuril region, the WorldClim matrices were transformed into a Gauss-Kruger projection (zone 25) with a 600-m resolution, which is in good agreement with the particularity of WorldClim data for the latitudes of the Kunashir Island.

The annual potential evaporation $E_{\mathrm{O}(\mathrm{yr})}$ is calculated as follows. First, the monthly and yearly evaporation capacities were calculated for the Yuzhno-Kurilsk station by N.I., Ivanov's formula [39]:

$$
E_{\text {o(mon) }}=0.0018 \cdot(25+t)^{2} \cdot(100-f) \text {, }
$$

where $t$ and $f$ are the monthly average temperature and relative humidity of the air, respectively. The annual amplitude of monthly evaporation rates is rather large and determined by the fluctuations of relative air humidity by $16 \%$. The maximum values $E_{\text {o(mon) }}=40-52 \mathrm{~mm}$ are typical of the second half of summer and autumn (September-November), when $f=73-86 \%$, i.e., is close to the annual minimum. In the first half of summer (June-July), relative air humidity increases to $94-95 \%$ and evaporation rate drastically decreases (making 12-13 mm per month), in spite of high air temperatures. The warmest month, August, takes an intermediate position. In this month, like in all other seasons of the year, the $E_{\text {o(mon) }}$ parameter is by $60-65 \%$ determined by temperature.

It has also been established that the annual monthly evaporation rate $(25 \mathrm{~mm})$ at the Yuzhno-Kurilsk station is close to the evaporation rate of August (21 mm), allowing us to take the relationship between $E_{0}(\mathrm{yr})$ and $t_{\text {Aug }}$ as directly proportional. On the basis of $t_{\text {Aug }}$ values, the annual evaporation rate was determined for each of the 32 test grounds of experimental area by the following formula:

$E_{\text {O(yr) }}=19.215 \cdot t_{\text {Aug }}-0.057 ; \quad \mathrm{R}=0.999$. (2)

The annual evaporation rate was also calculated by the data of 8 weather stations on the Kuril Islands:

$E_{\text {O(yr) }}=20.74 \cdot t_{\text {Aug }}-34.19 ; \quad \mathrm{R}=0.971$. (3) 
Insular-Arc Volcanic Ecosystems as Centres of Forming the New Parts of Continental Biosphere (by the example of South-Kuril Insular Ridge)

The results of calculations by both formulas differ insignificantly.

Then, the Vysotsky-Ivanov formula was used to calculate the atmospheric humidity factor $F_{\text {hum }}[39]$ :

$$
F_{\text {hum }}=r_{\text {yr }} / E_{0(\mathrm{yr})},
$$

where $r_{\mathrm{yr}}$ is the annual precipitation.

The $F_{\text {hum }}$ values at the experimental test site were in the range of 3.58-5.15, i.e., much higher than the known humidification values for oceanic plain subtaiga landscapes of the southern Far East [26]. An analogous level of atmospheric humidification is typical of "taiga highlands", according to V.B. Sochava [71]: subcontinental middle-mountain south taiga regions of East Siberia, e.g., the Khamar-Daban Range (true altitude $1442 \mathrm{~m}$, $F_{\text {hum }}=4.23$ ). Thus, the boreal forest communities of low-mountain island-arc Neo-Pacific were formed under the altitudinal-zonal hydrothermal conditions analogous to those of intracontinental "taiga highlands". This fact confirms the hypothesis [88] that the primary floristic complex on the Southern Kuril Islands was a high-mountain complex subsequently transformed by the intrusion of nemoral and ultranemoral species during oceanic transgressions and climatic changes.

The expenditure part of water balance the territory is composed of evaporation and the surface and groundwater flows. According to the theory of evaporation and transpiration [14], in case of sufficient and excessive atmospheric humidity $\left(F_{\text {hum }}>1\right)$, the total evaporation from the surface of closed canopy is represented almost solely by transpiration. Then, under the conditions of excessive atmospheric moisture and at a summer soil moisture content exceeding certain critical values $W_{\text {crit }}$ the evaporation rate is equal to total evaporation $E_{\mathrm{c}}$ [87]. For a 1-m soil layer, $W_{\text {crit }}=150 \mathrm{~mm}$, i.e., much lower than the values of summer soil moisture content for all plots of the experimental testing ground (see below). Thus, we accept that: $E_{\mathrm{C}(\mathrm{yr})} \equiv E_{\mathrm{O}(\mathrm{yr})^{*}}$

\section{Methods OF Local EMPIRICAL-STATISTICAL ModELing}

The author has elaborated the methods of discrete empirical-statistical modeling of natural ecosystems allowing operation with a relatively small number of the most informative characteristics.The information-statistical analysis of empirical material was performed by the methods described in $[6,50,73]$. These methods were employed to uncover thelandscape component interconnections. The main parameters of these connections are as follows: (1) the normalized coefficient of interrelation $C(A ; B)$ of two attributes taken in pairs: considered object - phenomenon $A$, and effecting on it factor $B$ and (2) the partial coefficient of connection $C\left(a_{i} / b_{j}\right)$ characterizing the closeness of interrelationship of individual classes (gradations) of these attributes. These gradations are marked in form of elements of the next sets: $A=\left\{a_{1}, a_{2}, \ldots, a_{i}, \ldots, a_{n}\right\}$ and $B=\left\{b_{1}, b_{2}, \ldots, b_{j}, \ldots, b_{m}\right\}$. Obviously, each phenomenon and each factor has a certain multitude of states.

The first parameter indicates the degree of general closeness of spatial interrelations between the attributes of forest ecosystem states. In the initial working matrix, the vector of states (gradations) of factor $B$ forms lines and the vector of states of phenomenon $A$ forms columns. The matrix cells contain probabilities, or frequencies, $p_{i j}$ of co-occurrence (probability) of the given states of $A$ and $B$. The sums by the columns and lines yield a priori (independent) probabilities $p\left(a_{i}\right)$ and $p\left(b_{j}\right)$, respectively; they are used to calculate the values of conditional probabilities $p\left(a_{i} / b_{j}\right)$. At the same time, a priori probabilities $p\left(a_{j}\right)$ characterize phenomenon $A$ under the assumption of its absolute independence of factor $B$, when $p\left(a_{i} / b_{j}\right)=p\left(a_{i}\right)$. The measure of difference between the conditional and a priori distribution of $A$ is function $I\left(A / b_{j}\right)$ equal to:

$$
I\left(A / b_{j}\right)=H(A)-H\left(A / b_{j}\right)
$$


Insular-Arc Volcanic Ecosystems as Centres of Forming the New Parts of Continental Biosphere (by the example of South-Kuril Insular Ridge)

$$
\text { where } \begin{aligned}
H(A) & =-\sum_{i=1}^{N} p\left(a_{i}\right) \log _{2} p\left(a_{i}\right), \\
H\left(A / b_{j}\right) & =-\sum_{i=1}^{N} p\left(a_{i} b_{j}\right) \log _{2} p\left(a_{i} b_{j}\right) .
\end{aligned}
$$

Parameter $I\left(A / b_{j}\right)$ is the measure of force of the general effect of this factor on the phenomenon. The higher is the $I\left(A / b_{j}\right)$ value, the more rigid is their connection. Parameters $H\left(A / b_{j}\right)$ and $I\left(A / b_{j}\right)$ are calculated for each line of the working matrix. The total amount of information, which is transferred from factor to phenomenon and characterizes the closeness of their connection, is equal to:

$$
T(A B)=\sum_{j=1}^{m} p\left(A / b_{k}\right) I\left(A / b_{k}\right) .
$$

The amount of information is estimated in binary units (bits); however, it is more convenient to use the relative measures of connection expressed in quotas of 1 . In the present study, the normalized coefficient of interrelation has been used:

$$
C(A ; B)=\frac{2^{\mathrm{T}(\mathrm{AB})}-1}{2^{H(\min A, B)}-1} .
$$

Here, $2^{T(A B)}$ is the number of general states of $A$ and $B$, while $H(A)$ and $H(B)$ are the common measure of diversity of characters $A$ and $B$, respectively. In accordance with the requirements of informational analysis, the statistical excerpt of a limited number of variables (in this case, less than 100 points) can be divided to no more than 5-6 classes (gradations). Our verification by criterion $\chi^{2}$ showed that parameter $C(A ; B)<0.07$ often seems to be inexact (interrelation of attributes below the $90 \%$ signification level) even at such a comparatively coarse quantization. Therefore, all connections with the coefficients below the specified threshold were excluded from the analysis.Note that $C(A ; B) \approx 0.19$ corresponds to correlation coefficient $0.65-0.70$ as well [73].

The second parameter $C\left(a_{i} / b_{j}\right)$, the partial coefficient of connection, made it possible to reveal the informational structure of relations in the binary "factor-phenomenon" system and thus to find some kind of ecological niches of each value (gradation) $a_{i}$ of phenomenon $A$ in the space of values $b_{j}$ of factor $B$. Parameter $C\left(a_{i} / b_{j}\right)$ made it possible to find some kind of ecological niches of each value (gradation) $a_{i}$ of phenomenon $A$ in the space of values $b_{j}$ of factor $B$. In ecology, it is quite permissible to apply two of the three known aspects of the conception of ecological niche [11, 64]: (1) spatial, close to the conception of site-inhabitance and (2) resource, determined by position of an object in relation to the gradients of some or other substance-energy factor (temperature, moisture content, physicochemical properties of soil, etc.). Taken together, both these aspects characterize the niche as a certain space of vital environmental factors.

Nevertheless the conception of niche is applicable not only to individual plant or animals but also to entire biotic communities, ecosystems, and their selected structure-function attributes [4]. According to R.H. Whittaker [94], we may generalize the notion and space of a niche, but the principles of the concept remain the same. The essence of such a generalization in the case of plant formations considered below is that attention is focused on the populations of coenosis-forming edificator species (after which the formations are named), rather than on the entire variety of constituent plant species.

Each niche is presented in the form of a row (descriptive) vector - a "fuzzy" set of the states of phenomenon $A$ caused by the given factor $B$. The row vector consists of standar-dized partial association coefficients:

$$
C\left(a_{i} / b_{j}\right)=\frac{p\left(a_{i} / b_{j}\right)}{p\left(a_{i}\right)}
$$


Insular-Arc Volcanic Ecosystems as Centres of Forming the New Parts of Continental Biosphere (by the example of South-Kuril Insular Ridge)

It is agreed that the association between $a_{i}$ and $b_{i}$ is significant at $C\left(a_{i} / b_{j}\right)>1$. The higher is the probability, the greater is the coefficient, therefore the components of row vector $C\left(a_{i} / b_{j}\right)$ are considered as "weighting" coefficients.

In the matrix of significant $(>1$ ) partial coefficients of connection, the phenomenon and the factor are graded by columns and lines, respectively. Factor gradations with the maximum values of coupling coefficient form a certain region of phenomenon dominance (here in after ecological dominant), while other gradations belong to the "fuzzy" part of the niche. If define the ecological domination in each vector-column of a niche by symbol " $x$ "and "fuzzy" links of the niche by symbol "•", then we will obtain a formalized matrix of climatic niche. In this form, the matrix clearly demonstrates the character and closeness of connections (see below Figures 9 and 10). Many characteristics of forest ecosystems have not only the fundamental ecological niche for some factor or another (with the respective ecological dominant and the "fuzzy" part of the niche) but also a kind of enclave separated from the niche on the graph of partial coefficients by more than one gradation of the factor. The attention was also paid to the cells of binary ordination of the phenomenon with the factor, where $C\left(x_{i} / y_{j}\right)$ $\leq 1$. These were the regions of sporadic distribution of the given phenomenon by the gradient of changes in the factor under consideration, frequently with the emergence of an enclave.

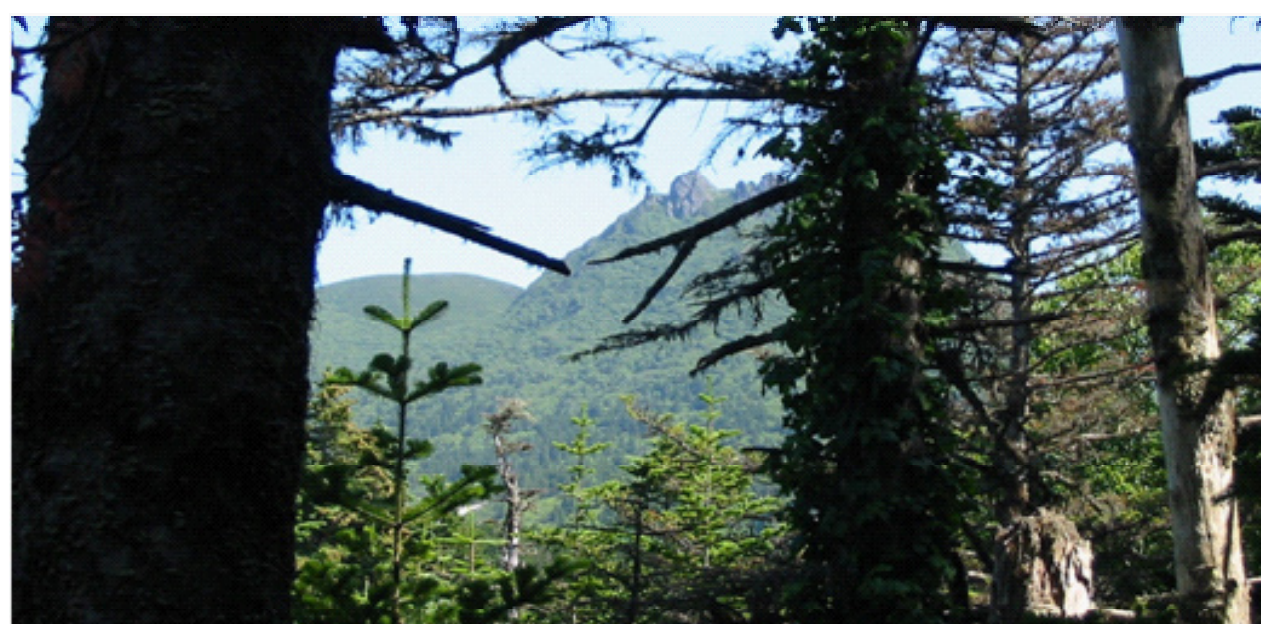

Fig9. The mountain spruce/fir forest in the lower layer of the Mendeleev volcano. There is a well marked alteration of generations of the stand.

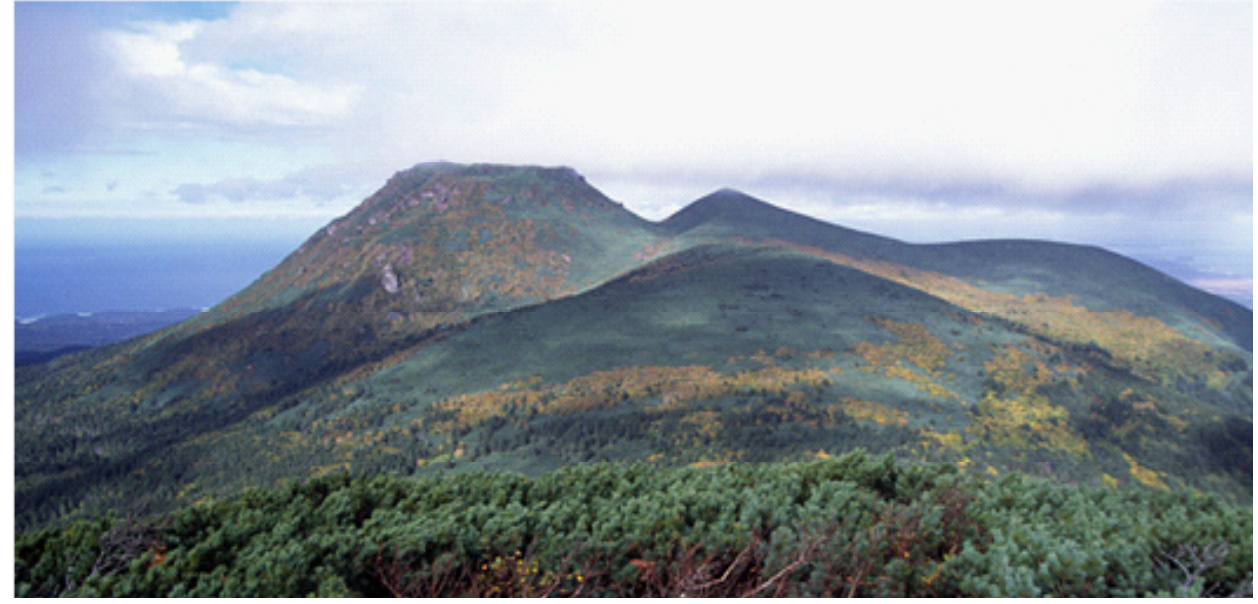

Fig10. The subgoltsy zone with cedar elfin wood and goltsy in the upper zonal layer of the Men-deleev volcano. 
Insular-Arc Volcanic Ecosystems as Centres of Forming the New Parts of Continental Biosphere (by the example of South-Kuril Insular Ridge)

The system of ecological niches was used to calculate the taxonomic norms of functional characteristics of the given object. Thereto, the central values of all gradations of the factor were used, as well as the matrix of the normalized partial coupling coefficients of the object introduced into the calculations as "weight" coefficients. The normal value or, in other words, the weighted average value of the functional feature [74], was determined as a sum of products of central values of all its gradations by the "weight" coefficient corresponding to the given gradation of the phenomenon (object).

\section{REgiONAL BIOCKIMATIC SYSTEM OF THE SOUTH-KURIL ISLANDAS}

The regional bioclimatic system is understood as an ordered set of spatial relationships between plant formations, as well as their groups and classes, according to [82], and landscape-geophysical factors. The elements of the system are the climatic niches of phytocoenological units mentioned above, which are distributed along the hydrothermal gradients and represent the spatialand resource, according to Eu. P. Odum [64], aspects of ecological niches. The regional bioclimatic system imposes the boundary conditions of the formation of phytocoenotic units of the topological level (associations, their groups and classes) under the refracting influence of local geomorphological and edaphic factors.

\section{Climatic-Forming Factors}

The regional bioclimatic system of the Southern Kuril Islands is formed, first, by the warm (the Sea of Okhotsk, Soya) and cold (the Pacific Ocean, Kuril, or Oyashio) sea currents washing them on the northwest and southeast, respectively, and, second, by the monsoon circulation of air masses, with a drastically marked wind rose: northwestern continental in winter and southeastern oceanic in summer. Rather contrasting climates of the Sea-of-Okhotsk and Pacific coasts, as well as the adjacent slopes of volcanic ridges and separate volcanoes, are formed due to the interference of the above factors.

The geographical positions of the islands become highly important in this context. The Southern Kuril Islands, together with the Hokkaido Island, are situated in the focus of frontal systems of the northwestern part of the Pacific Ocean - in the narrow western part of the northern moderate belt in the Pacific Ocean, where the meridian countermovement of warm and cold waters drastically increases the energy activity of the ocean with enhanced moisture and heat transfer to the atmosphere [51]. The main trajectories of tropical cyclones bringing heavy rainfall and increasing the atmospheric humidity factor up to 3.5-4.5 and more pass exactly through this zone (see Figure $2 c$ hereinafter).

The regional diversity of climates is determined first of all by air mass circulation. The wind roses of the Kunashir Island (Fig. 11), as well as most islands of the Kuril Ridge, are characterized by drastic seasonal contrasts, with the dominance of northwestern wind currents in winter and the winds of S-SE-E-NE courses in summer. It was considered as a manifestation of monsoon climate pattern [45, 52]. It was believed that the Sea-of-Okhotsk coast of the Southern Kuril Islands differs from the Pacific coast in the colder and drier winter (the winter continental monsoon) and warmer summer. In summer, the Pacific coast is more humid and cloudy, with frequent fogs, due to the cold and moist winds of oceanic monsoon. Later on it was shown that the climate on the islands is generally oceanic (with mild winters and cool summers) and the monsoon pattern of changes in the direction of prevailing winds is caused by the seasonal shifts (East $\leftrightarrow$ West) of cyclone trajectories [91]. Nevertheless, in the vegetation period, the Sea-of-Okhotsk sector remains warmer and drier than the Pacific one. The "cold" oceanicity, which is unfavorable for the growth of forest vegetation, is still more marked on the islands of the Lesser Kuril Ridge washed by the cold Kuril Current (Fig. 12).

The latest cartographic materials [40] have made certain adjustments to the climatic situation described. It has been established that, first, the trajectories of the major cyclones in this region pass in the general direction from southwest to northeast and must bring nearly equal amounts of rainfall to both island sectors. Second, the 
Insular-Arc Volcanic Ecosystems as Centres of Forming the New Parts of Continental Biosphere (by the example of South-Kuril Insular Ridge)

southern half of the Kunashir Island is washed by the branch of the warm Soya sea current on both sides. This branch approaches first the northwestern coast of the island and then, after passing along the Kunashir Strait, the southeastern coast. Though, upon the turn to the northeast, the current fades away; theref ore, its thermal effect on the Pacific sector of the island must decrease, which is confirmed by the contrasts in the structure and phenological regime of phytobiota between the marine and oceanic sectors. Nevertheless, the effect of marine currents prove to be not so strong as to substantially $[28,29]$ distort the altitudinal-belt (zonal) bioclimatic regularities on volcanoes and volcanic ridges of the Southern Kuril Islands.

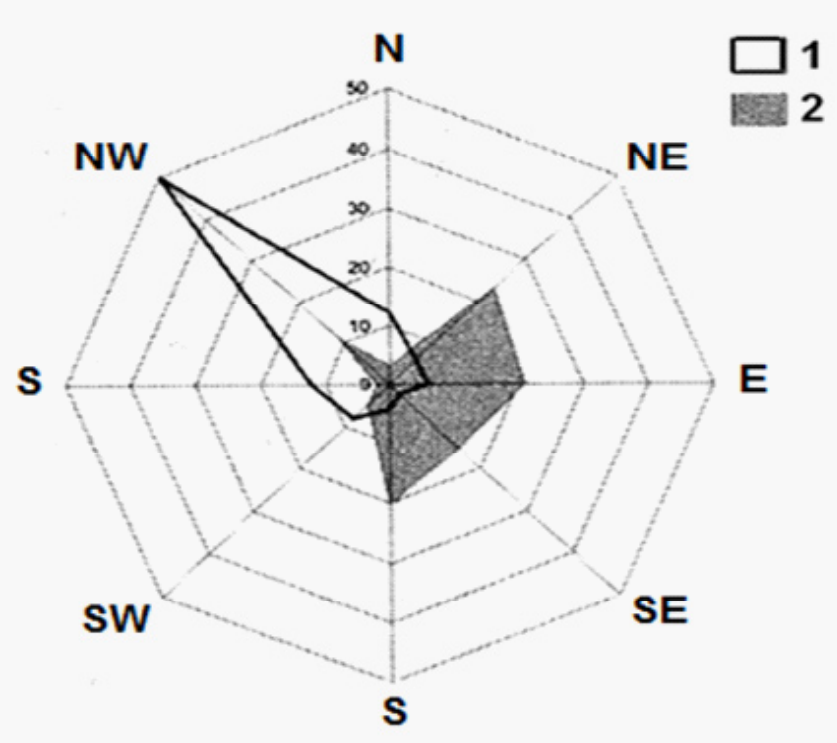

Fig11. The wind rose by the Yuzhno-Kurilskweather station (the Kunashir Island). 1 - January; 2 - July.

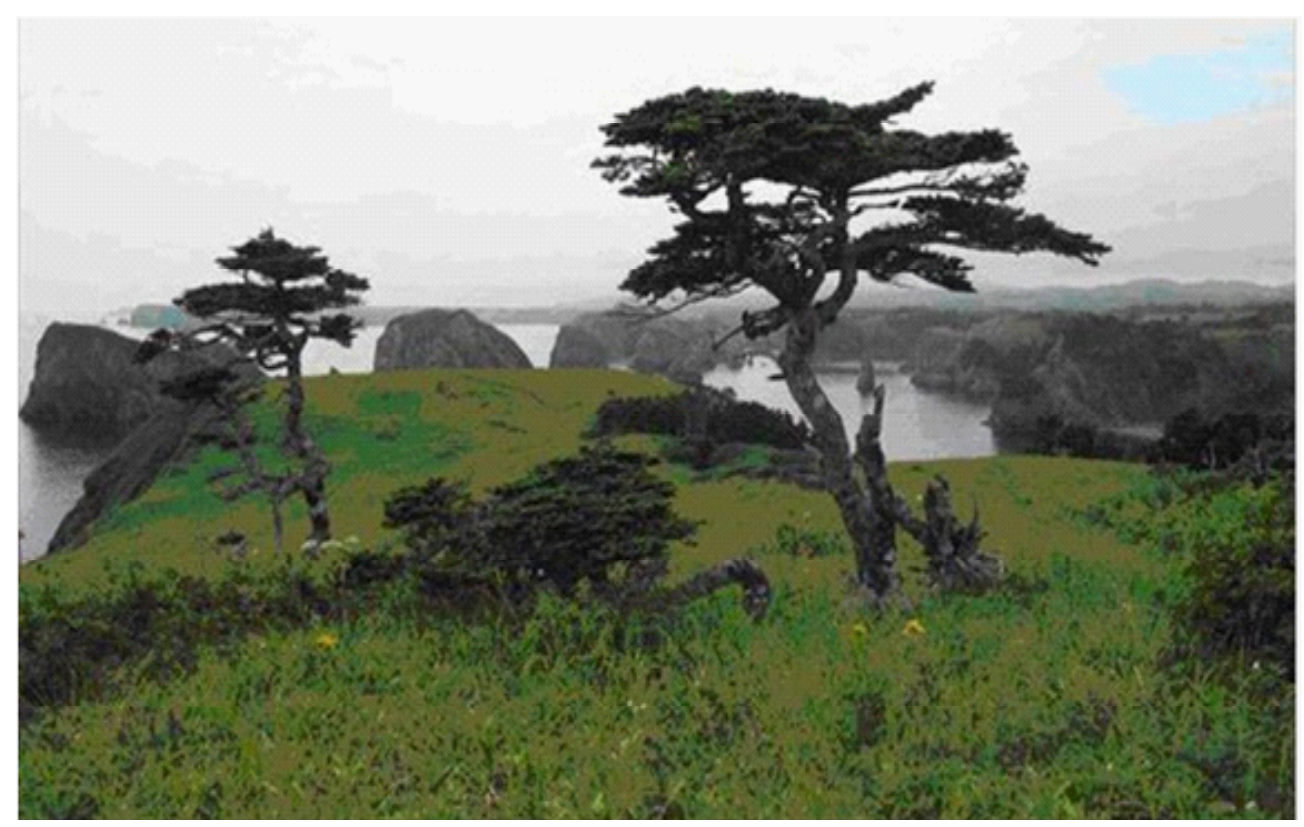

Fig12. The Shikotan Island. Sparse stunted trees with flag- and umbrella-shaped crowns and crooked trunks against the background of the dominant herbaceous vegetation. 
Insular-Arc Volcanic Ecosystems as Centres of Forming the New Parts of Continental Biosphere (by the example of South-Kuril Insular Ridge)

It is also believed that the main factors of climate on the Kuril Islands are the air mass circulation and temperature regime of the Sea of Okhotsk [46]. In winter, the islands are exposed to the Siberian anticyclone; in summer, the marine tropical air brings the moisture for monsoon rainfalls and dense fogs.

\section{The Problem of Oceanicity and Continentality}

This problem is associated not only with the latitude and longitude system of sea and ocean currents and with the respective air mass circulation but also with the complicating influence of the mountain-valley terrain. The latter terrain forms intermontane-kettle continental and mountain suboceanic climates on the continental margin and the adjacent insular land, as well as the climates of "warm" and "cold" oceanicity on the coasts and in the foothills. Let us add here the dynamic events of the "barrier foot" and "barrier shade" created by the effects of orography on monsoon air mass circulation; as a result, the above oceanic types of climate become still more humid or, on the contrary, more arid.

The bioclimatic contrasts have a distinct localization even on the Kuril Ridge islands. As it has already been mentioned, the Sea-of-Okhotsk coasts of the Kunashir and Iturup Islands in the warm half of the year are much warmer than the Pacific Ocean coasts. These sublatitudinal hydrothermal contrasts are quite clearly manifested also on the Mendeleev Volcano (Fig. 13). Accordingly, the vegetation period in the former case is longer than in the latter case, while the homonymous phases of development of the same plant species (e.g., maple, mountain ash, honeysuckle, bird cherry tree, Shiksha (crowberry), Actinidia, lianas, etc.) come 8-12 days earlier [92].

In accordance with the above, we consider the altitudinal-zonal structure of plant cover of the Mendeleevo testing ground for the two opposite sectors: the northwestern Sea-of-Okhotsk sector, which is warmer and drier in the vegetation period, and the southeastern Pacific sector, which is colder and more humid. It should be noted, however, that the temperature contrasts are most marked on the plains and in the foothills and gradually smoothed out with rising up the mountains, coming to naught in the subgoltsy belt (see Fig.13a). The pluviometric sector contrasts can be traced over the entire height of volcanic low mountains. Accordingly, sector contrasts are maintained in the humidity factor, though slightly decreasing with height (see Fig.13c).

The advection of maritime air masses causes frequent and durable fogs in the spring-summer season, giving a significant increase in precipitation (not taken into account by weather stations) in the lower mountain belt and in the foothills (on the coasts). In the regions of "foggy shade" (e.g., under the shelter of the Otdelnaya -Mendeleev-Mechnikov mountain system), in summer there are much more sunny and, accordingly, warm weathers compared to the open coast, which must contribute to the higher structural and functional development of phytobiota.

The substantial import of precipitation by fogs seems also to smooth out the vertical pluviometric gradients. It is represented, e.g., by the large altitudinal-zonal amplitude of distribution of dark-coniferous species on the Kunashir Island: from the stone birch crooked forests on volcanic slopes to piedmont mixed forests coming nearly to the coast line.

Hence, the correlation between dark-coniferous (fir/spruce) and oak forests as indicators of climate oceanicity and continentality, respectively, seems to be an important problem. In sub-Pacific, a considerable part of the Sea-of-Japan slope of the Southern and Middle Sikhote-Alin is occupied by oak forests, especially the coast (with islands) and the foreranges. On the Kunashir Island included in the more oceanic Neo-Pacific, there are widespread mixed (broad-leaved/dark-coniferous) forests coming along the middle and high marine terraces (80-100 $\mathrm{m}$ in height) directly to the coastline. Oak is a dominant only in forests of the littoral part of the island, which faces the Pacific Ocean, with a simultaneous decrease in the height of forest stands (up to the shrub-thicket form of oak forest on the coast, with ugly stems and "flag" crowns). Low oak forests grow on the coastal ledges of terraces, at their foot along the coastline (by the internal slopes of beach ridges) and along the beds of short river valleys cutting terrace edges. In miniature, it resembles the floro- and phytocoenotic change 
Insular-Arc Volcanic Ecosystems as Centres of Forming the New Parts of Continental Biosphere (by the example of South-Kuril Insular Ridge)

on the eastern macroslope of the Middle Sikhote-Alin [54]. Such oak forests occur much less frequently on the coast of the Sea of Okhotsk. According to the data of [92], oak associations with maple grow in internal regions of the Iturup island, with the weaker oceanicity and the presence of flat and hilly sites. Closer to the sea, they are replaced by stone birch forests.

a)

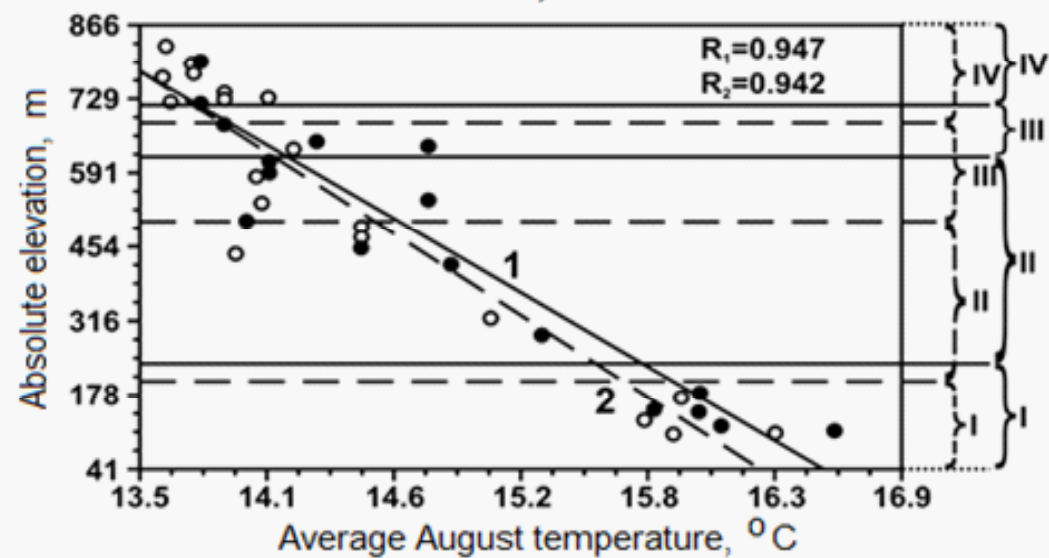

b)

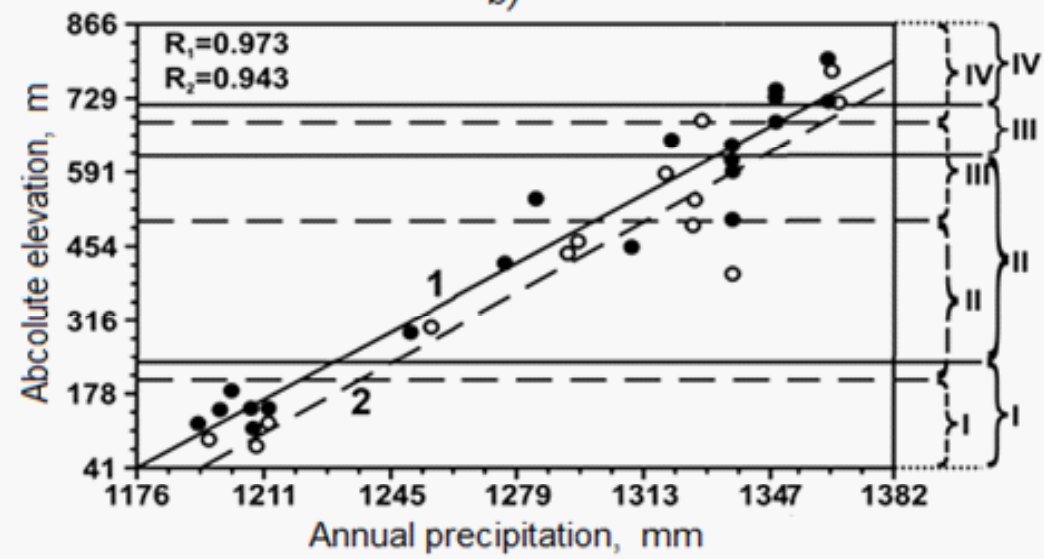

c)

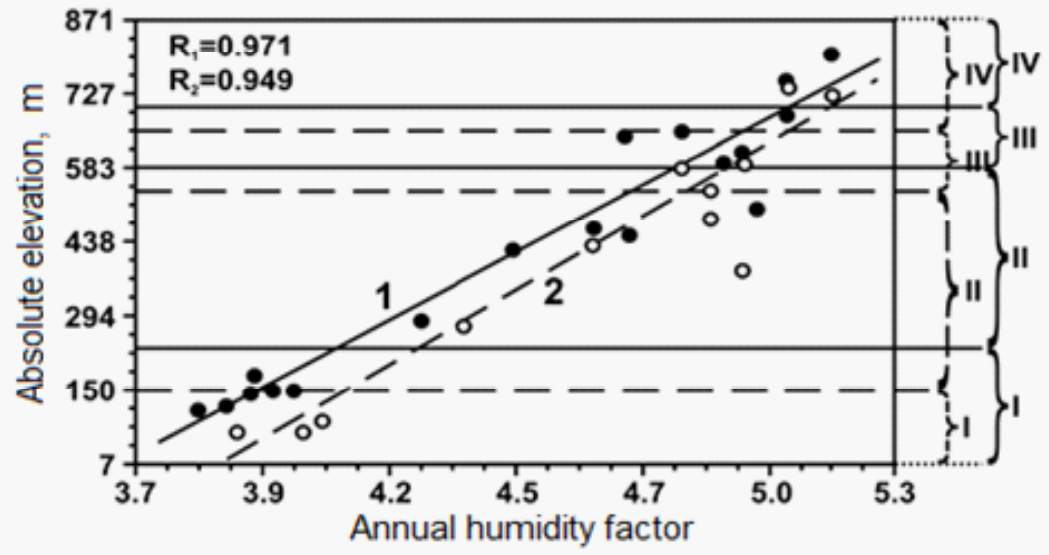

Fig13. The Mendeleev Volcano landscape. 
Insular-Arc Volcanic Ecosystems as Centres of Forming the New Parts of Continental Biosphere (by the example of South-Kuril Insular Ridge)

Distribution of the mean August air temperature (tVIII), annual precipitation (ryr) and Vysotsky-Ivanov humidity factor (Fhum) by true altitude (Habs).

The averaged linear regression equations:

(a) tVIII $=0.162-0.00033 \cdot \mathrm{Habs} ; \quad \mathrm{R}=0.925$;

(b) ryr $=1187+0.2396 \cdot$ Habs; $\quad \mathrm{R}=0.946$;

(c) Fhum $=3.77+0.0019 \cdot$ Habs; $\quad \mathrm{R}=0.945$.

Altitudinal belts: I, coniferous/broad-leaved forests; II, dark-coniferous forests; III, stone birch crooked forest; IV, cedar elfin wood. The boundaries between the altitudinal belts in the sectors of: 1 , the Sea of Okhotsk; 2 , the Pacific Ocean.

It is beyond doubt that the major cause of such mosaic distribution of forest vegetation in the moderate belt of the Pacific Ocean mega ecotone should be sought in the refracting influence of submeridionally stretching mountain ridges on the monsoon, generally sublatitudinal, air mass circulation, with predominant influence of continental katabatic winds in the cold half of the year. Oak is a xerophylic and frost-resistant species and ipso facto is an indicator of enhanced continentality of the climate. It is a matter of regional peculiarities of heat and moisture transfer by air masses. The Sikhote-Alin eastern slopes are an area of descending air flows not only in winter but also in mid-seasons, with adiabatic drying of vegetation. The drying is stronger closer to the coast.

Consequently, the coastal oak forests of Sikhote-Alin emerged as a result of winter continental monsoon and periodic breakthroughs of strong withering continental winds in mid-seasons (which we observed on the Putyatin Island in the second half of September, 1984). The hydrothermal conditions of eastern slopes of the ridge are unfavorable for dark-coniferous taiga even in summer due to the circulation of summer oceanic monsoon in the south of the Far East. Here, not only in winter but even in summer (consequently, all year round), air masses move generally eastwards; therefore, the Sea-of-Japan slopes of Sikhote-Alin and, to a lesser extent, the Pacific slopes of Southern Kuril ridges and volcanoes are in the "rain" shade, which is an additional factor of bioclimatic aridization together with the cold Primorskoye and Kurilskoye ocean currents.

This oro-climatic phenomenon is typical not only of the Neo-Pacific boreal bioclimatic belt but also of the sub-Arctic belt, as is exemplified by the patterns of vegetation distribution over volcanic slopes on the Simushir Island [29]. There are 4 formations on the western (Sea-of-Okhotsk) slope of the volcano: the meadow (the true altitude of 20-50 m), the stone birch forest (80-150 m), the alder/cedar elfin wood (150-1130 m), and the mountain tundras (1130-1360 m). The eastern (Pacific) slopes have only 2 formations: the cedar elfin wood/alder $(50-930 \mathrm{~m})$ and the rare spots of mountain tundras among naked volcanic surfaces.

Thus, the mountain orography of marginal-continental and insular land, namely, the sub-meridian stretching of ridges parallel to the coastline, causes the longitudinal-sectoral inversion of elements of the "continentality/ oceanicity" bioclimatic system. The water area of the Sea of Japan exerts a direct effect on land only within a narrow coastal strip, coming to naught already at a small distance from the coast. Obviously, "oceanicity" should be calculated in the direction of the main moisture and heat transfer but not by a formal distance from the coastline. Here, the water balance of differently oriented river basins may be a good indicator of the degree of influence of the ocean, according to I.N. Gartsman [22].

\section{The Structure of Bioclimatic System of Neo Pacific Landscapes}

It is known that the smaller is the island remote enough from the mainland, the more its climate is like that of the ocean; therefore, the basic bioclimatic, hydrological and morphosculptural features of islands are determined 
Insular-Arc Volcanic Ecosystems as Centres of Forming the New Parts of Continental Biosphere (by the example of South-Kuril Insular Ridge)

by their areas $[37,38]$. With increasing insular land area, the degree of moist oceanic air mass transformation by the latter and the level of moisture condensation are enhanced, the altitudinal bioclimatic differentiation of landscapes begins from higher altitudes [19] and, finally, the altitudinal zones are extended. Simultaneously with the increasing areas of water catchment basins, the runoff also increases and becomes more stable and, accordingly, the erosion-accumulation processes in the river network become more intensive, creating a more developed fluvial morphosculpture. Analogous patterns can be also observed on greater spatial and temporal scales: during the transition of subaerial landscapes from island-arc (NeoPacific) to marginal-continental (sub-Pacific) stage of development. A striking example is the Kunashir Island (Mendeleev Volcano)/Middle Sikhote-Alin binary operation system considered below.

In addition, there is a definite relationship between the structure of altitudinal zonality and the height of low-mountain construction per se. On the Dokuchayev Ridge of the Kunashir Island, the increase in the upper boundary of dark-coniferous forests from $400 \mathrm{~m}$ (the Fregat Mountain) to $630 \mathrm{~m}$ (the Gerasimov Mountain) is almost directly proportional to the increase in mountain height from $501 \mathrm{~m}$ to $906 \mathrm{~m} \mathrm{[22].}$

The researchers have already mentioned the very clear and fairly complete manifestation of altitudinal-zonal bioclimatic zonality on the Mendeleev Volcano, in spite of its relatively low height [55]. At the same time, the territory of the volcano is in the general series of zonal boundaries becoming naturally lower as the general oceanicity of the climate increases and the height of mountain systems on the Kuril Islands decreases[90].

Let us consider the structure of altitudinal zonality on the volcano (Table 1, Fig.14). In general, vegetation belts in the Sea of Okhotsk sector are at higher altitudes compared to the Pacific Ocean sector. According to the basic concepts of mountain climatology [4], it may be supposed that the climate of the first sector is less oceanic, with more marked inter-belt boundaries. On the opposite slope of the volcano, under the conditions of higher oceanicity, the inter-belt geobotanic boundaries are not only lower (the spruce/fir forest belt reaching the coast in some places) but also much "fuzzier". At the same time, the vast phytoecotones (the rudiments of buffer forest communities) are formed precisely under these conditions. Three such ecotones were found in the sample areas on the Mechnikov Mountain slopes: one binary ecotone separating the belts of cedar elfin wood and stone birch crooked forest (the true altitude of about $640 \mathrm{~m}$ ) and two ternary ecotones, with equal participation of spruce, stone birch and cedar elfin wood, at the upper boundary of the dark-coniferous belt (the altitudes of 580-590 m). Finally, in close proximity to the Pacific Ocean coast, on the ancient marine terrace overlapped with pyroclastic material, there was a buffer broad-leaved/spruce/ fir community at the altitudes of about $70 \mathrm{~m}$ in the mixed forest belt, with dominant broad-leaved species. The latter example demonstrates that even at the island-arc stage of subaerial landscape development there was a massive invasion of representatives of the Manchurian nemoral-forest flora into the Okhotsk dark-coniferous flora, with the formation of buffer dark-coniferous/broad-leaved forests.

Table1. The true altitudes ( $m$ ) of boundaries between altitudinal vegetation belts of the Mendeleev Volcano and surrounding territories

\begin{tabular}{|c|c|c|}
\hline \multirow[t]{2}{*}{ Altitudinal belt } & \multicolumn{2}{|c|}{ Sector } \\
\hline & Sea of Okhotsk & Pacific Ocean \\
\hline Cedar elfin wood & \multirow[t]{2}{*}{$700-720$} & \multirow[t]{2}{*}{$670-680$} \\
\hline Stone birch crooked forest & & \\
\hline \multirow[t]{2}{*}{ Dark-coniferous forests } & $\begin{array}{c}\text { 610-620 (in some areas, } \\
\text { decreases to } 540 \text { ) }\end{array}$ & $\begin{array}{l}520-580 \text { (in some areas, } \\
\text { decreases to } 480-500 \text { ) }\end{array}$ \\
\hline & \multirow[t]{2}{*}{$230-250$} & \multirow[t]{2}{*}{$230-250$} \\
\hline Coniferous/broad-leaved forests & & \\
\hline
\end{tabular}




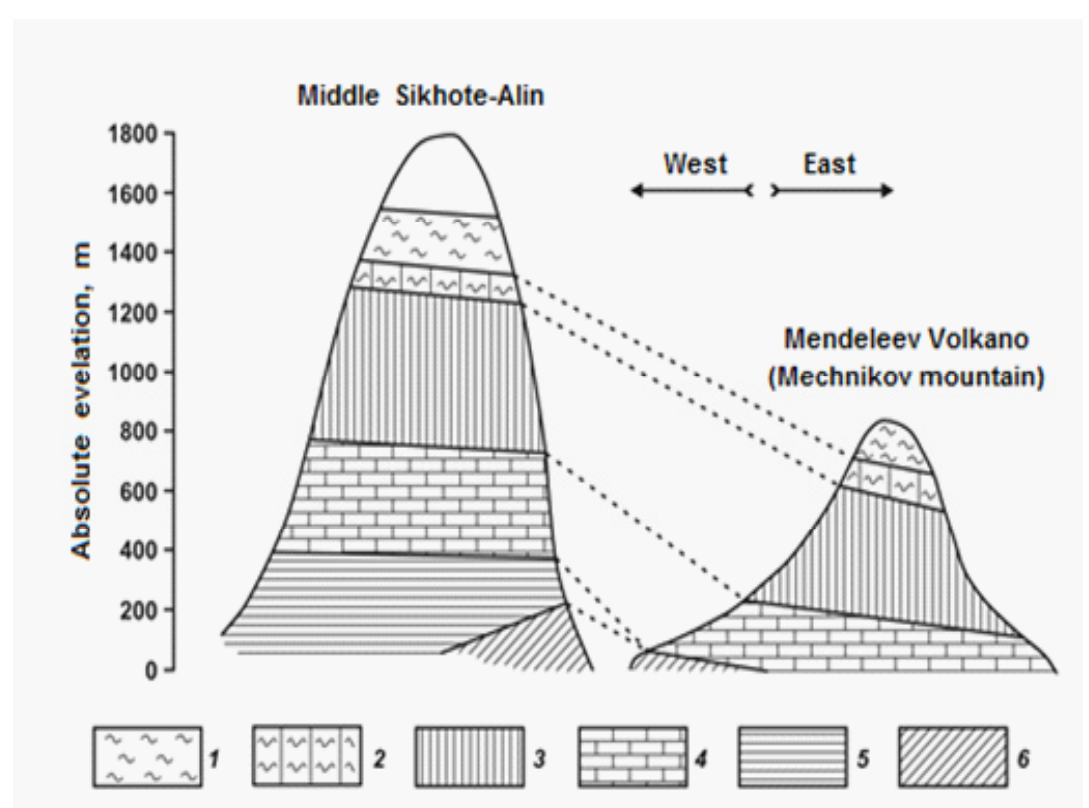

Fig14. The schemes of altitudinal zonality in the Middle Sihkote-Alin, according to [31], and the Mendeleev Volcano on the Kunashir Island.

Altitudinal bioclimatic belts: 1 - subgoltsy creeping forests (cedar elfin wood); 2 - stone birch crooked forest (often with cedar elfin wood in undergrowth); 3 - dark-coniferous fir/spruce fo-rests (on the Middle Sikhote-Alin, with an admixture of larch); 4 - spruce/broad-leaved forests; 5 - cedar/broadleaf forests (absent on Kunashir); 6 - broad-leaved forests, mainly derivative.

The altitudinal-zonal boundaries presented in Table 1 are highly generalized and abstracted from the effects of other factors, which are extensively reported in the literature on insular biogeography. Of course, this altitudinal-zonal system does not imply the absence of certain associations outside its main boundaries. The stone birch and cedar elfin wood communities are especially eurytopic in this respect; on the Kunashir and Iturup Islands, they intrude into the dark-coniferous taiga belt here and there and even go down to the very sea coast, being indicative of the phenomena of substantial local refraction of altitudinal zonality by geomorphological, microclimatic and edaphic factors. The breakthrough of shrubby and creeping vegetation into taiga forest vegetation seems to have long historical roots and to be determined by the biological resistance of the latter vegetations, their local adaptation in the post-glacial period during warming and the movement of the taiga belt upper boundary up the slopes [88].

The altitudinal belts on the Kunashir Island are generally lower compared to the Middle Sikhote-Alin (see Fig.14) due to a significant difference between these regions in the degree of oceanicity-continentality, which fits into the general pattern of these changes for highlands. At the same time, the level of atmospheric moisture content of this territory is of crucial importance. The comparison of altitudinal-zonal bioclimatic conditions of, e.g., the Alps and Great Caucasus, as well as Western and Central Caucasus, gives a visual representation for the European sector of Eurasia [24]. In the external (moist) regions of the Alps, up to the high-mountain stratum, annual precipitation is greater by $500-1000 \mathrm{~mm}$ than on the northern macroslope of the Western Caucasus; therefore, the upper boundary of the forest belt corresponding to the annual precipitation of about $2000 \mathrm{~mm}$ has a true altitude of about $1700 \mathrm{~m}$ and $2200-2300 \mathrm{~m}$, respectively. At the same time, the upper boundaries of subalpine crooked forests are at the altitudes of 2200 and $2800 \mathrm{~m}$, respectively. The simplest calculations 
Insular-Arc Volcanic Ecosystems as Centres of Forming the New Parts of Continental Biosphere (by the example of South-Kuril Insular Ridge)

made on the basis of these data have shown that the lowering of altitudinal belts in the Alps by $300-500 \mathrm{~m}$ compared to the Greater Caucasus corresponds to the increase in annual precipitation by $200-400 \mathrm{~mm}$, i.e., the pluviometric stage of the lowering of altitudinal belt boundaries is $75 \mathrm{~m} / 100 \mathrm{~mm}$ on average.

Table 3 presents the temperature parameters and annual precipitation, as well as heat to moisture ratios, recorded at weather stations in the south of the Far East, which characterize different zonal/subzonal landscapes of the continental margin, the Sakhalin Island, and the Kuril Islands. The stations are situated in descending order of the sums of biologically active temperatures, which made it possible to rank them among the respective types/ subtypes of landscapes, according to [36].

With regard to the sums of active temperatures and annual precipitation, the above weather stations were placed on a simplified diagram of climaareals of natural ecosystems in the territory of the Former USSR [9], which allowed us to establish the positions of marginal-continental, continental-insular and island-arc landscapes in the hydrothermal field of the boreal belt of the Pacific Ocean mega ecotone (Fig. 15).

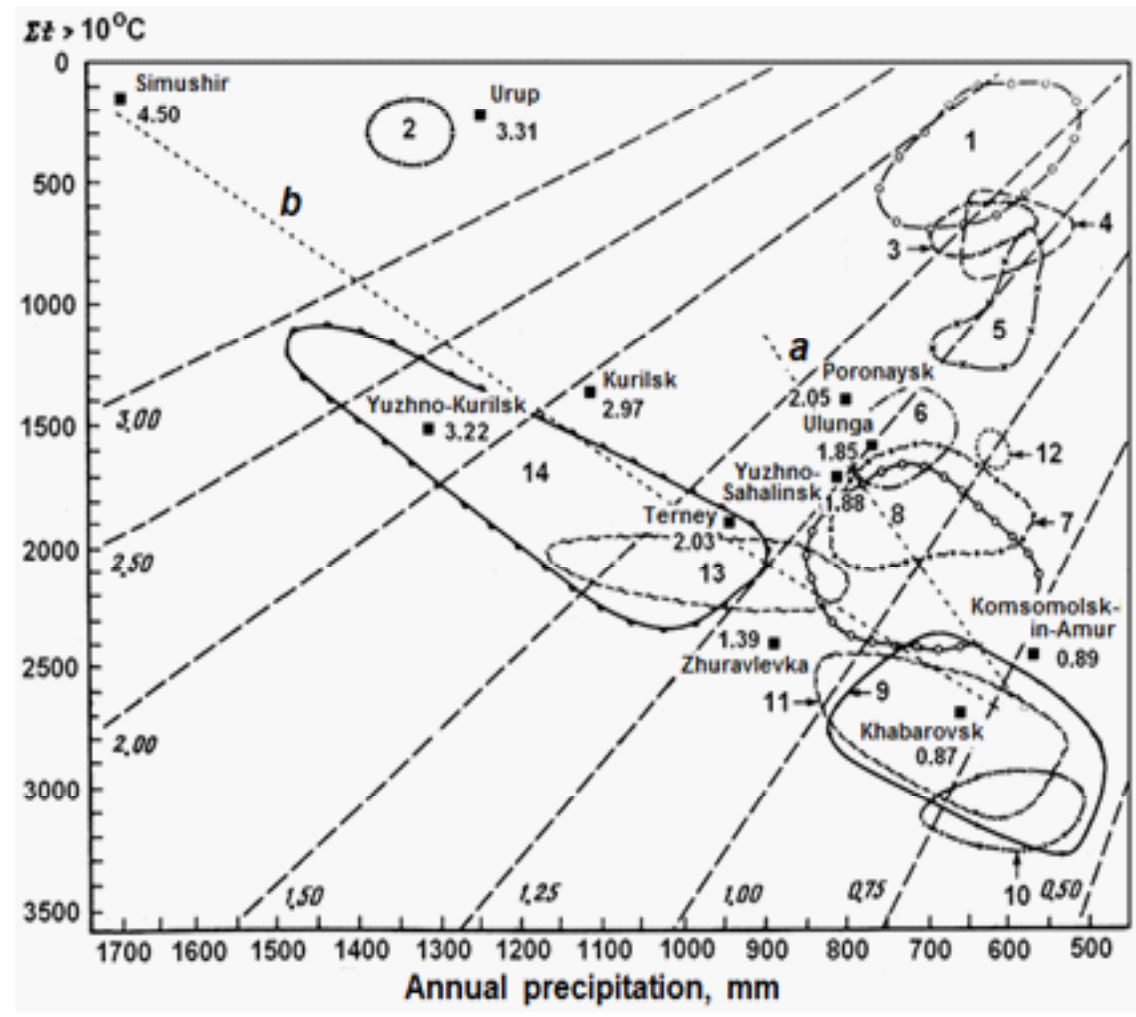

Fig15. The positions of weather stations in the southern part of the Far East in the system of climaareals of natural ecosystems in the territory of the former USSR, according to [6], with supplements.

The diagram of climaareals clearly shows the two "beams" of an inversely proportional relationship between heat supply and moisture content. Beam $(a)$ describes the hydrothermal trend in the direction from lowland plains of the Lower Priamurye to middle mountains of the Middle Sikhote-Alin continental macroslope and to the Sakhalin Island. This trend fits into the gradient hydrothermal field of transitions from East European oak forests to subtaiga and then to south- and middle-taiga geo(eco)systems. During this transition, the sums of active temperatures decrease and annual precipitation increases, with the respective increase in $F_{\text {hum }}$ from $0.70-0.90$ to 1,15-1,30. According to the climatic zoning by [3], this beam 
Insular-Arc Volcanic Ecosystems as Centres of Forming the New Parts of Continental Biosphere (by the example of South-Kuril Insular Ridge)

characterizes the landscape-geophysical conditions of subcontinental sector of the Russian Federation. Such conditions are consequently typical of the boreal sub-Pacific of the Pacific Ocean mega ecotone: its marginal-continental sector with the adjacent continental islands.

The second beam $(b)$ begins, like the first one, with sub-continental territories; however, then it goes through the climaareals of forest ecosystems of much more humid (sub-oceanic and oceanic) regions. It covers the broad-leaved forests in the foothills of southwest Ukraine and the mountain spruce forests of the Carpathian Mountains and successively "strings" the middle mountains of the western macrosclope of the Middle Sikhote-Alin and the Sea-of-Japan coast of the continent, then the Southern Kuril Islands and, finally (with a large spread), the Middle Kuril Islands.

This beam, within the framework of NeoPacific, describes the latitudinal-zonal change of bioclimatic conditions that would be interesting to compare with the altitudinal-zonal hydrothermal field at the experimental test ground of the Mendeleev Volcano (see Table 2). The Yuzhno-Kurilsk station gives humidity factor values (3.22) rather close to the values for the surrounding piedmont-plain coniferous/broad-leaved forests of the Mendeleev landscape (3.43 on average). However, the more northern Urup and Simushir stations situated in the zones of birch crooked forests and cedar elfin woods, respectively, give the lower $F_{\text {hum }}$ values (3.31 and 4.50) compared to their altitudinal-zonal analogs in the Mendeleev volcanic landscape (4.70 and 5.02). In the island-arc region, as one can see, the altitudinal-zonal hydrothermal field is more contrasting than the latitudinal-zonal field, which must cause more marked phytocoenological differences on the slopes of volcanic mountains and ridges compared to the transitions in the bioclimatic system of altitudinal zonality.

Table2. The hydrothermal characteristics of forest ecoregions of the boreal belt on the Pacific Ocean mega ecotone of Northern Eurasia.

\begin{tabular}{|c|c|c|c|c|c|}
\hline \multirow{2}{*}{$\begin{array}{c}\text { Weather stations } \\
\text { (absolute altitude, } \mathrm{m})\end{array}$} & \multicolumn{5}{|c|}{ Hydro-thermal characteristics ${ }^{*}$ ) } \\
\cline { 2 - 6 } & $\mathrm{tVII}-$ VIII & $\sum \mathrm{t} \geq 10 \mathrm{o}$ & $\mathrm{E} 0, \mathrm{~mm}$ & ryear & Fhum \\
\hline
\end{tabular}

Subboreal landscapes

\begin{tabular}{|c|c|c|c|c|c|}
\hline Khabarovsk (87) & 21.1 & 2672 & 755 & 657 & 0.87 \\
\hline Komsomolsk-in-Amur (21) & 20.0 & 2413 & 650 & 577 & 0.89 \\
\hline Zhuravlevka (215) & 19.8 & 2366 & 633 & 879 & 1.39 \\
\hline
\end{tabular}

Boreal south-taiga landscapes

\begin{tabular}{|c|c|c|c|c|c|}
\hline Terney (27) & 17.4 & 1802 & 463 & 939 & 2.03 \\
\hline Yuzhno-Sakhalinsk (23) & 17.3 & 1779 & 457 & 870 & 190 \\
\hline Yuzhno-Kurilsk (23) & 15.8 & 1426 & 390 & 1255 & 3.22 \\
\hline
\end{tabular}

Boreal middle-taiga landscapes

\begin{tabular}{|c|c|c|c|c|c|}
\hline Ulunga (763) & 16.3 & 1544 & 409 & 759 & 1.85 \\
\hline Poronaysk (3) & 15.8 & 1426 & 390 & 1027 & 2.63 \\
\hline Kurilsk (38) & 15.3 & 1309 & 373 & 1108 & 2.97 \\
\hline
\end{tabular}

Subarctic landscapes

\begin{tabular}{|c|c|c|c|c|c|}
\hline Urup (73) & 11.1 & 322 & 360 & 1230 & 3.42 \\
\hline Simushir (26) & 10.4 & 157 & 379 & 1706 & 4.50 \\
\hline
\end{tabular}


Insular-Arc Volcanic Ecosystems as Centres of Forming the New Parts of Continental Biosphere (by the example of South-Kuril Insular Ridge)

*) tVII - VIII - average temperature of most warmonth; $\sum \mathrm{t} \geq 10 \mathrm{o}$ sum of the biological active temperatures, OC; E0, mm - annual potential evaporation, $\mathrm{mm}$; ryear - annual precipitation, mm;Fhum - annual humidity factor.

Table3. The comparison of the main climatic characteristics of altitudinal-zonal plant communities of the Mendeleev volcanic landscape and analogous format-ions of the marginal-continental sector of the Pacific Ocean mega ecotone of Northern Eurasia

\begin{tabular}{|c|c|c|c|c|c|}
\hline \multirow[t]{2}{*}{ Regions } & \multirow{2}{*}{\multicolumn{2}{|c|}{$\begin{array}{l}\text { Altitudinal zonal plant communities and } \\
\text { formations (in brackets - altitude, m) }\end{array}$}} & \multicolumn{3}{|c|}{ Climatic parameters } \\
\hline & & & $\begin{array}{l}\text { t VII--VIII } \\
\text { ryear, mm }\end{array}$ & $\begin{array}{c}\sum t \geq \\
100\end{array}$ & Fhum \\
\hline \multirow{10}{*}{$\begin{array}{l}\text { Kunashir } \\
\text { Island, } \\
\text { Mendeleev } \\
\text { volcanic } \\
\text { landscape. } \\
\text { Plant com- } \\
\text { munities }\end{array}$} & \multirow{2}{*}{\multicolumn{2}{|c|}{$\begin{array}{l}\text { Lowland and piedmont dark/coniferous-broad- } \\
\text { leaf forests with subtropical elements }(20-250)\end{array}$}} & 16.0 & 1473 & 3.43 \\
\hline & & & 1207 & & \\
\hline & \multirow{4}{*}{\multicolumn{2}{|c|}{$\begin{array}{l}\text { Lowland and low-mountain dark-coniferous } \\
\text { (spruce/fir) forests with nemoral elements } \\
\qquad(120-600)\end{array}$}} & & & \\
\hline & & & 14.6 & 1144 & 4.64 \\
\hline & & & 1299 & & \\
\hline & & & & & \\
\hline & \multirow{2}{*}{\multicolumn{2}{|c|}{$\begin{array}{l}\text { Subalpine stone birch elfin woodland with } \\
\text { admixture of spruce and with cedar elfin in } \\
\text { undergrowth }(540-700)\end{array}$}} & 14.4 & 1097 & 4.70 \\
\hline & & & 1320 & & \\
\hline & \multirow{2}{*}{\multicolumn{2}{|c|}{ Subalpine cedar elfin wood (650-800) }} & 14.1 & 1027 & 5.02 \\
\hline & & & 1347 & & \\
\hline \multirow{12}{*}{$\begin{array}{c}\text { Low Priam- } \\
\text { urye and } \\
\text { Middle } \\
\text { Sikhote-Alin. } \\
\text { Plant } \\
\text { formations }\end{array}$} & \multirow{5}{*}{$\begin{array}{l}\text { Lowland and piedmont broadleaf } \\
\text { and coniferous- } \\
\text { broadleaf tall grass forests }\end{array}$} & st. Neran (221) & 19.6 & 2319 & 1.40 \\
\hline & & & 865 & & \\
\hline & & & & & \\
\hline & & st. Zhuravlevka & 19.8 & 2366 & 1.38 \\
\hline & & $(215)$ & 875 & & \\
\hline & \multirow{4}{*}{$\begin{array}{l}\text { Middle-mountain fir/spruce } \\
\text { dwarf-bush/grass forests } \\
\text { with nemoral elements }\end{array}$} & st. Ulunga (547) & 16.3 & 1544 & 1.83 \\
\hline & & & 749 & & \\
\hline & & st. Irumka (516) & 16.7 & 1638 & 1.78 \\
\hline & & & 761 & & \\
\hline & Northern-taiga middle- and & ст. Sophiysky & 15.1 & 1262 & 2.06 \\
\hline & high-mountain larch light & Priisk (903) & 757 & & \\
\hline & forests, cedar elfin woods & & & & \\
\hline
\end{tabular}

Foot-note: t VII--VIII - average temperature most warm month, oC; 
Insular-Arc Volcanic Ecosystems as Centres of Forming the New Parts of Continental Biosphere (by the example of South-Kuril Insular Ridge)

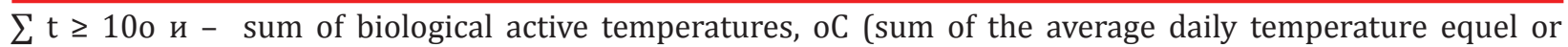
higher 10o); ryear - annual precipitation; Fhum - Vysotsky-Ivanov's annual atmospheric humidity factor. Denominations of continental plant formations are given by [68].

\section{Altitudinal Bioclimatic Stages}

The data from Tables 2 and 3 and Fig. 15 were used to calculate the pluviometric stage by comparing weather stations on the Southern Kuril Islands with those on plains and in low mountains of the Lower Priamurye and the Middle Sikhote-Alin, respectively. The upper boundaries of the coniferous/broad-leaved and dark-coniferous/taiga belts on the Mendeleev Volcano were shown to be lower by 550 and $620 \mathrm{~m}$, respectively, compared to the analogous marginal-continental region mentioned above (see Fig. 15), which was adequate to the increased annual precipitation in the foothills by $400-650 \mathrm{~mm}$. The average values of the pluviometric stage obtained for the upper boundaries of coniferous/broadleaf forests and the fir/spruce forest belt (Table 4) slightly exceed the stage calculated for the sub-oceanic mountain territories of southern Europe (see above), which is quite typical of the monsoon-oceanic region, being evidence of the reality of the altitudinal zonality/atmospheric water content ratios obtained for southern Kunashir.

Table4. The altitudinal pluviometric (a), thermometric (b) and hydro-thermometric (c) stages of lowering of zonal-belt boundaries in the south of the Kunashir Island compared to the Middle Sikhote-Alin.

\begin{tabular}{|c|c|c|c|}
\hline \multirow{2}{*}{ Upper altitudinal zonal boundaries } & \multicolumn{3}{|c|}{ Altitudinal stages (n / 100 m) } \\
\cline { 2 - 4 } & $\mathrm{a}$ & $\mathrm{b}$ & $\mathrm{c}$ \\
\hline Dark-coniferous/broadleaf forests & $10 \mathrm{~mm}$ & 0.760 & 0.405 \\
\hline Dark-coniferous (spruce/fir) forests & $89 \mathrm{~mm}$ & 0.680 & 0.360 \\
\hline
\end{tabular}

The thermometric stage was calculated by analogy, based on the mean temperature of the warmest month: for the Yuzhno-Kurilsk station $\left(15.8^{\circ}\right)$ and for the Ussuri and the Lower Amur plains (around $20.0^{\circ}$ on average for eight stations). Finally, the stages of the complex hydrothermal index (the Vysotsky-Ivanov humidity factor) were calculated.

It would be interesting to note that the thermometric stage on the Kunashir Island is more than twice higher than the altitudinal temperature gradient, which is here about $0.35^{0} / 100 \mathrm{~m}$, i.e., generally close to the low temperature gradient typical of insular territories, according to $[37,38]$. Thereat, the entire system of altitudinal-zonal boundaries shifts downwards and the altitudinal zonality range becomes contracted. It is precisely the great spread of the thermometric stage compared to the altitudinal temperature gradient that reflects the decrease in condensation level on the islands, as is postulated by [19]. The smaller is the island area, the more efficient is this process. Thus, the stone birch crooked forest belt in the south of the Kunashir Island begins at the altitudes of 520-620 m (see Table 3) but descends to the altitudes of 30-40 m on the neighboring smaller Shikotan, in much the same way as on the larger, more northern, Iturup Island [92].

The obtained values of landscape-geophysical stages for the regional shifts of the two most important altitudinal-zonal boundaries can be accepted as tentative for predictive calculations of statistically significant shifts in altitudinal belts on the Mendeleev Volcano according to particular scenarios of global climate changes. As we can see, the upper boundary of the fir/spruce forest belt must be more sensitive to global climatic signal than its lower boundary; hence, e.g., one should expect the narrowing of this belt in case of warming and/or increase in atmospheric moisture content or broadening in case of cooling and/ or aridization. Accordingly, the areals of the lower coniferous/broad-leaved forests, as well as the higher subgoltsy stone birch crooked forest with cedar (and alder) elfin wood, must change too. 
Insular-Arc Volcanic Ecosystems as Centres of Forming the New Parts of Continental Biosphere (by the example of South-Kuril Insular Ridge)

It would be interesting to note that the group of weather stations on the continental coast of the Sea of Japan, the southern and middle parts of the Sakhalin Island, and the Southern Kuril Islands is within a comparatively narrow range of the sums of biologically active temperatures but considerably different in atmospheric moisture content, which is the major climatic factor of drastic biogeographical differences between the island-arc Neo-Pacific and the marginal-continental and continental-insular Sub-Pacific.

The comparison of the presented diagram of climaareals (see Fig. 15) with the ecological-phytocoenotic complexes in the south of the Far East [85] raises a number of fundamental problems that require special consideration. So, the lowlands of the Middle and Lower Priamurye (the Khabarovsk and Komsomolsk -on-Amur stations), on the one hand, and littoral plains in the southern part of the Kunashir Island (the Yuzhno-Kurilsk station), on the other hand, are ranked within the same ecological-phytocoenotic complex of nemoral and subnemoral coniferous/broad-leaved forests. At the same time, the climaareals of these complexes differ very dramatically, especially in annual precipitation and, accordingly, in humidity factor.

For comparison, let us give the boundaries of altitudinal belts in the two southern territories of the Far East being at the same latitude as the Kunashir Island: the Southern Sakhalin and the southern part of the Middle Sikhote-Alin $[40,91]$. The mountain ranges of the former and latter regions were formed at the turn of Mesozoic and Cenozoic eras and in the epoch of Mesozoic folding, respectively. On Sakhalin, the belt of spruce/fir forests rises to a level of about $700 \mathrm{~m}$ and the belt of stone birch forests and crooked forests rises to $900-1000 \mathrm{~m}$, with the belt of cedar elfin wood above them (up to 1100-1200 m). In the Middle Sikhote-Alin, the above vegetation belts go even higher. Even on the ridge slopes facing the Sea of Japan, with bioclimatic borders being lower by 150-200 m compared to the continental (western) slopes, the mountain belt of spruce/broad-leaved forests occupies the range of heights from 350-400 $\mathrm{m}$ to $650-700 \mathrm{~m}$, while the upper boundary of the dark-coniferous forests located above has an altitude of 1200-1250 m. After a comparatively narrow strip of stone birch crooked forests, beginning from the altitude of $1300-1350 \mathrm{~m}$, there is the cedar elfin wood belt with the upper boundary of $1550-1600 \mathrm{~m}$.

Thus, under the climatic conditions of insular boreal Neo-Pacific, the basic range of altitudinal zonality (from nemoral forests to subalpine crooked forests and elfin woods) is reduced and compressed simultaneously, if compared with the analogous ranges of zonality of large continental islands and the more so the continental margin. On volcanogenic islands, this range keeps within the limits of the low-mountain layer of macrorelief. This altitudinal-zonal phytocoenotic compression is considered as a phenomenon of extra zonality of insular biotic system formed by pendulum-like changes in the formations and even types of plant cover during the alternation of Quaternary glacial and interglacial epochs [89]. It should be noted that the transition from coniferous/broadleaf forests via taiga to subgoltsy elfin wood, which is extremely limited in space, occurs notwithstanding the decreasing vertical temperature gradient above the islands.

The phenomenon of compression and general lowering of the system of altitudinal bioclimatic belts has been traced not only on the super-regional scale of meridian sectors of the Pacific Ocean mega ecotone but also at the level of separate landscape districts of the Kuril Ridge, e.g., within the Kunashir Island. The comparative analysis of altitudinal zonality of separate mountain massifs of the island along the Dokuchaev Ridge has shown that the rise of the lower boundary of birch crooked forests from $400 \mathrm{~m}$ to $630 \mathrm{~m}$ is proportional to the increase in mountain height from $500 \mathrm{~m}$ to $915 \mathrm{~m}$. It is associated with the soil-ground moisture content, which is determined by slope length [29]. Such explanation is rather questionable. According to the laws of climatology [4], the continentality of mountain climate increases and the upper boundaries of altitudinal belts shift upwards with the increasing massiveness of the mountain.

\section{Evolutionary Significance of the Island-Arc Bioclimatic System}

Thus, the main spectrum of altitudinal bioclimatic zonality originates at a rather early stage of subaerial landscape development, when the tectonic-volcanic massifs emerging from the ocean have not yet gone beyond 
Insular-Arc Volcanic Ecosystems as Centres of Forming the New Parts of Continental Biosphere (by the example of South-Kuril Insular Ridge)

the limits of lowland relief. In this case, it is neogenic age of the morphostructural basis of the Kunashir Island, with quaternary volcanism planted on it. The climatically determined compression of altitudinal zonality on the Mendeleev Volcano, as well as along the entire Kurile Ridge, shifts the regional bioclimatic contrasts (which are usually widespread in mountains inside the continents and even on their margins) to the local (topological) level. It can be assumed that the topological bioclimatic system of island-arc Neo-Pacific is a kind of focus ("core") of the origin of continental (zonal, sectoral and altitudinal-zonal) biogeographical and landscape structures. Later on, with transition to the marginal-continental regime, the hierarchic level of these structures increases from topological to regional level, as is manifested in the general rise of bioclimatic borders and simultaneous broadening of altitudinal belts.

The special geobotanic studies of the Klyuchevskaya Group of volcanoes in the Central Kamchatka (close to the northern boundary of the boreal belt) have shown [76] that the time necessary for the formation of the conditionally indigenous forest communities at the initial stages of subaerial biogenesis is: (1) no less than 150-200 years for stone birch crooked forests; (2) 250-300 years for cedar elfin wood with single forest stands; and (3) 2000-2500 years for upright coniferous forests. At the same time, forest communities develop much more rapidly on a loose pyroclastic substrate than on lava platforms of different age. In the Southern Kunashir ecoregion and close to the southern boundary of the boreal belt, the above time intervals should be significantly reduced.

Each new part of continental biosphere in the Northwest Pacific emerges under environmental conditions highly unfavorable for the zonal types of forest phytobiota: unstable morphotectonic regime, critical hydrothermal and edaphic conditions. However, precisely these regimes and conditions are the strong stimulating factors of evolutionary processes in young island-arc geo(eco)systems yet having no rich florogenetic and phytocoenological diversity.

All of the evolutionary changes in biota are based on its close interaction with the environment. In the history of organic world on the Earth, as is known, the new forms of life (species, populations and communities) emerged in the geological and climatic epochs critical for the biota: orogenesis, intensification of volcanic activity and global cooling [16]. In these epochs, the stabilizing selection predominating in antecedent warm climatic periods changed for disruptive selection creating a certain diversity of species and communities (allogenesis) with higher specialization, i.e., adapted to the tighter conditions of existence [69, 99]. At the same time, the rate of selection increased with the decrease in the quantity of populations [79]. It was due to the factor of pressure of population waves [86]. This process can be considered as a "... homeostatic evolutionary reaction of a population" [77, p. 213].

The novel types of ecological systems in the temperate latitudes emerged in the last glacial period [10]. Moist taiga forests with ancient (eopleistocene) well-developed soils existed on the Kuril Islands since Early Pleistocene [88], which allows us to consider this period as the beginning of evolutionary processes in the plant cover of these islands.

\section{Initial Evolutionary Biosphere Processes In THE INSUlaR-ARK VolCANic LAND SCAPES}

\section{Structure Organization of Insular Volcanic Landscape}

The modeling results provided a much stricter and more streamlined insight into the known concept of "fuzziness/discontinuity" of altitudinal-zonal boundaries on NeoPacific islands and the "leveling" of these boundaries by local factors [21, 38, 92]. Distribution of groups of forest 1types (GFT) for Mendeleev volcano landscape is presented on Fig.16. This map was created by L.S. Sharaya with the help of the education of logistical multiple regression: 
Insular-Arc Volcanic Ecosystems as Centres of Forming the New Parts of Continental Biosphere (by the example of South-Kuril Insular Ridge)

$$
\begin{aligned}
& \ln (G F T)=0.002617 \cdot Z_{+14.13}-0.8907 \cdot \cos \left(A_{45}\right) / G A_{-2.79}+ \\
& +0.01125 \cdot[\operatorname{GrW}(10-20)]_{+2.44}-0.03613 \cdot t(40)_{-1.59}+0.1289 . \\
& \left.R^{2}=0.919 ; \quad \operatorname{Degr}=5.0 \%\right) ; P<10^{-6},
\end{aligned}
$$

Hereln $(G F T)$-logarithmic series of groups of forest types, which are distributed by altitude; Z - absolute elevation; $\cos \left(A_{45}\right) / G A$ - north-west component of exposition for gentle sloping; GrW(10-20) - moisture vertical gradient in soil layer 10-20 cm; $t(40)$ - temperature of soil on depth $40 \mathrm{~cm}$. The subscripts of each predictor are $t$-statistics; their module determines the significance of contribution of predictors to the spatial variability of temperature. $R^{2}$ is the coefficient of determination and $P$ is the statistic characterizing the probability of error in the establishment of statistical dependence.
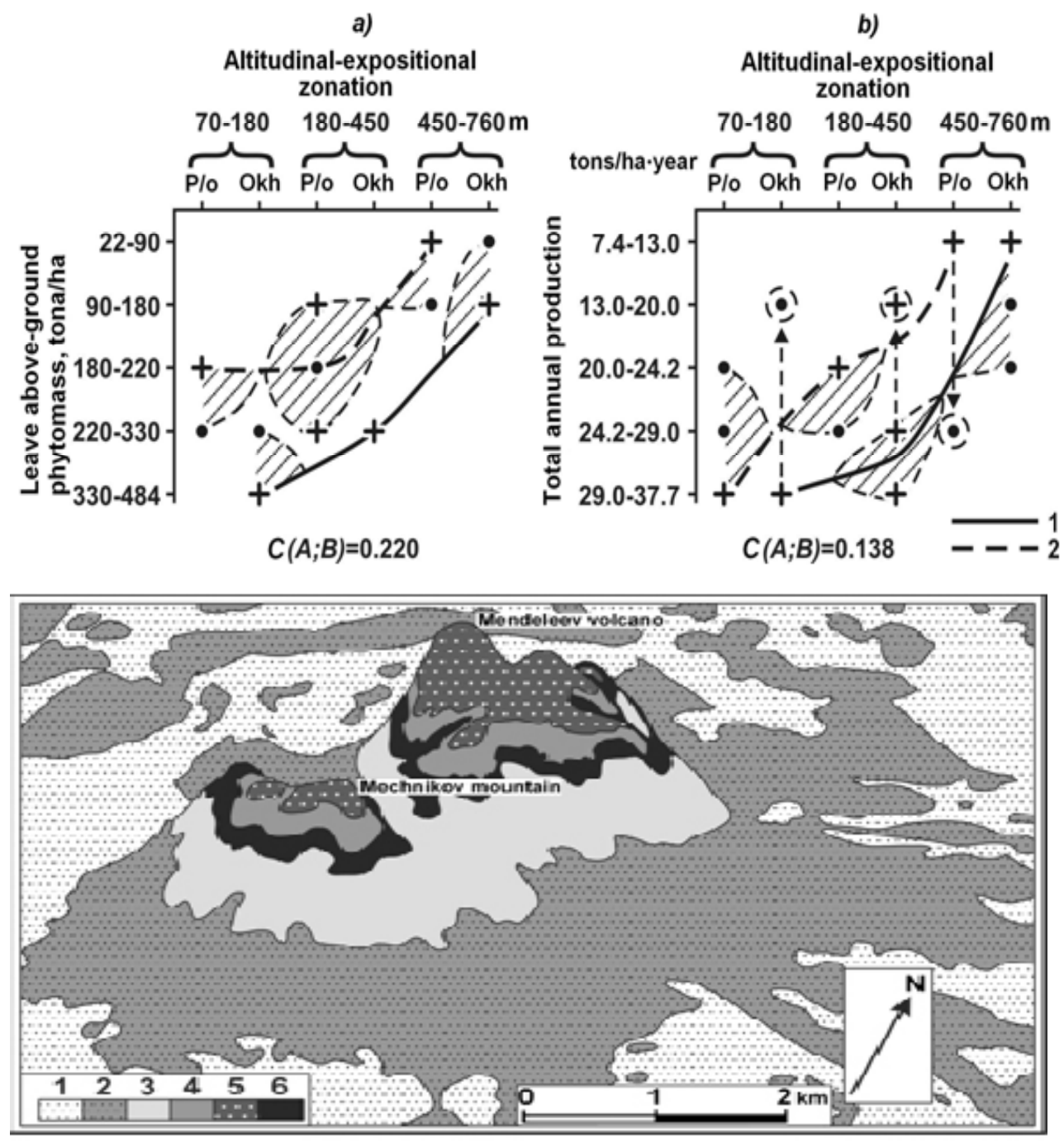

Fig16. The map of the groups of forest types on the Mendeleev volcano landscape.

The map has been calculated and created by L.S. Sharaya by methods, given an account of[79]. 1-6- the groups of forest types (see in the text). 
Insular-Arc Volcanic Ecosystems as Centres of Forming the New Parts of Continental Biosphere (by the example of South-Kuril Insular Ridge)

The model (9) describes $92 \%$ of $P$ variability in space by means of comprising factors. The model was successfully verified (tested) by Allen's cross-validation [2]: the empirical criterion (Degr $<50 \%)$ shows that the predictive strength of the model is sufficient for predictive mapping or calculating the characteristic at new points.

The Mendeleev volcano is characterized by highly distinct and rather complete manifestation of altitudinal bioclimatic zonality (Fig.17), in spite of its relatively low altitude, and this phenomena already was noted in the literature [55]. The volcano territory settles down in the general series of regular lowering of altitudinal-zonal boundaries along with the increase in overall oceanicity of the climate and decrease in the height of mountains on the Kuril Islands [90].

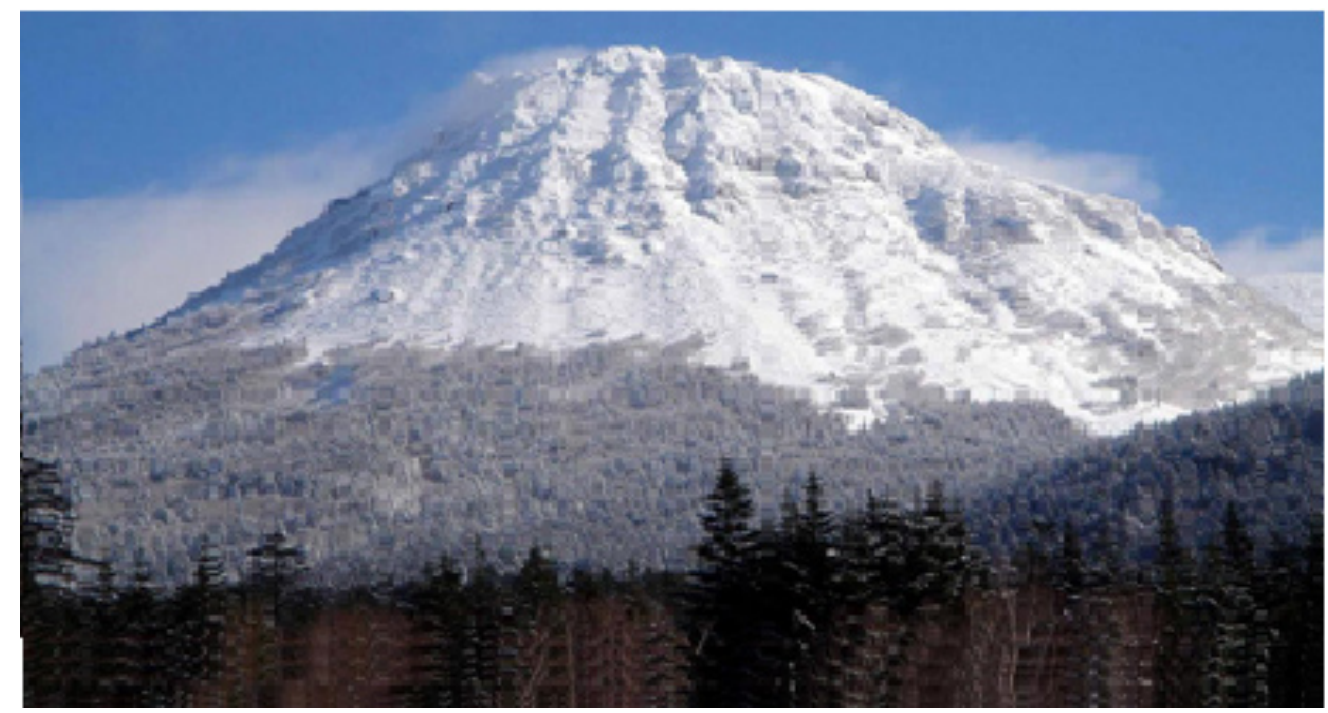

Fig17. Common appearance of Mendeleev volcano in winter season.

Altitudinal geobotanic zonation is expressed enough distinctly. The piedmont zone of fir-silver forests is on the foreground. Higher on low part of slopes this is the zone of stone-birch elfin woodland with cedar prostrate shrubs. Yet higher, right up to apex, this is zone of cedar prostrate shrubs which spend the winter in snow.

The inter-component connections in the Mendeleev volcanic landscape are presented by the general information model (Fig.18). These connections are organized into a highly determined system based on the predominant factor of true altitude. It forms low-mountain microlandscapes (by strata), has a direct effect on the floro- and phytocoenotic structures, and determines the lithoedaphic and hydrothermal boundary conditions of their distribution. The altitudinal zonality discloses the basic feature of bioclimatic system at the stage of island-arc biogeocoenosis: direct subordination of phytobiota to vertical hydrothermal gradients. Inthe Priamurye Sub-Pacific and in the VolgaRiver basin, with their more continental climate, the altitudinal zonality in low mountains is weak, being "obscured" by other abiotic factors (expositional, lithogenic, etc.); in the insular landscape of NeoPacific, it is the leading and strongest abiotic factor of biogeocoenotic organization (Fig.19). This fact indicates that insular biogeosystems are exposed to direct influence of the respective background climatic system from the very beginning of their emergence, being yet in the grip of the ocean.

The influence of the factor of solar-circulation exposure on floro- and phytogenesis in a volcanogenic-island ecosystem is quite distinct but more than three times weaker compared to the influence of true altitude. The obtained quantitative estimates do not confirm the concepts (which are based only on visual observations) [21, 
Insular-Arc Volcanic Ecosystems as Centres of Forming the New Parts of Continental Biosphere (by the example of South-Kuril Insular Ridge)

$37,38]$ of the exceptionally high disturbance of altitudinal zonality on the Kuril Islands by the exposure factor. Itisalsoobviousthatthe ecosystems of island-arc Neo-Pacific are highly sensitive to the global climatic changes: the background hydrothermal signal is transmitted to phytobiota directly and only with certain adjustment by the exposure factor and microrelief forms. It seems to be the cause of the known instability of insular phytobiota, its climatogenic dynamicity.

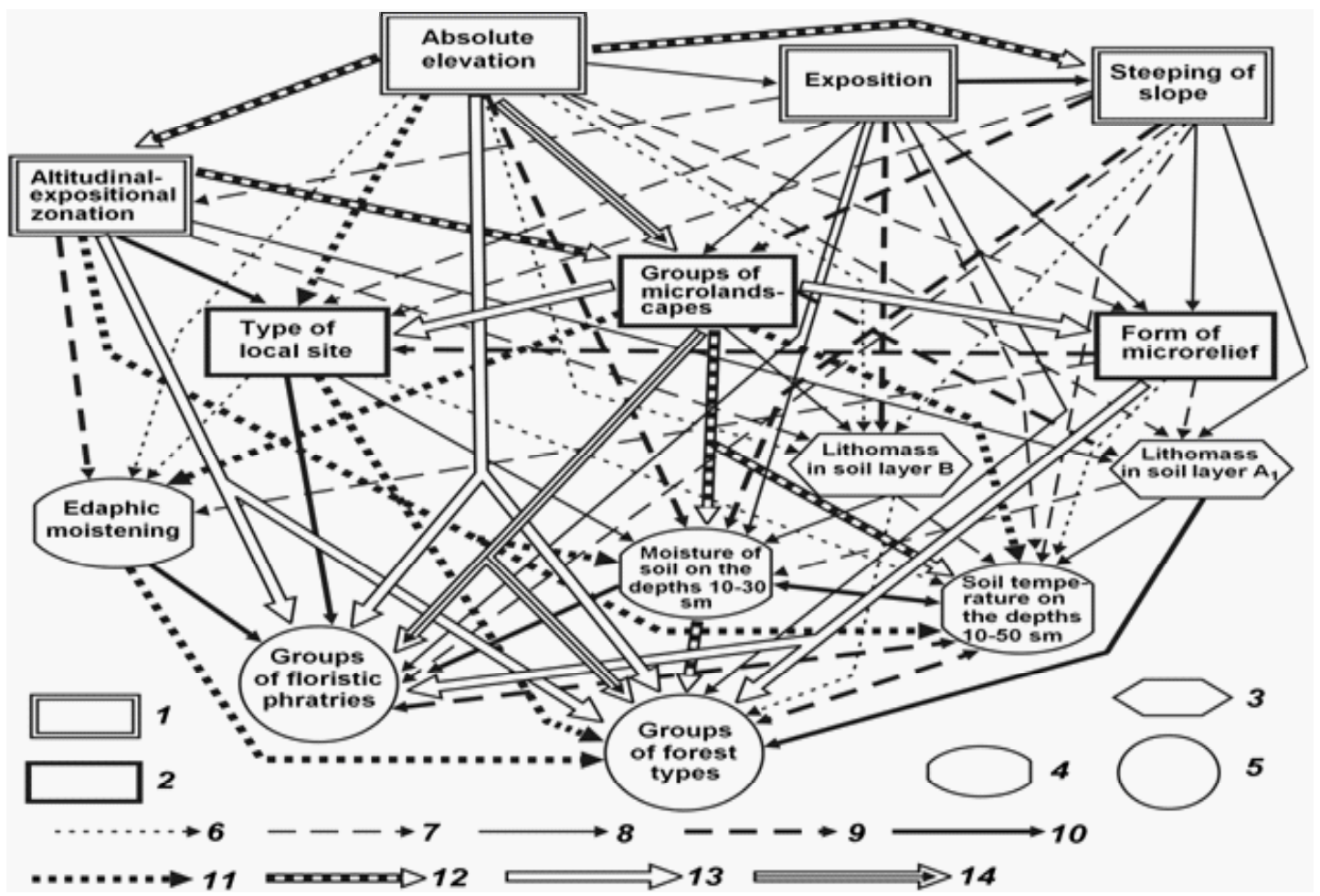

Fig18. General information-statistical model of geocomponent interrelations for low mountain ecoregion of Mendeleev landscape.

Geocomponent blocks: 1 - initial abiotic factors; 2 - second abiotic factors-retranslat-ors; 3 -hydro- and thermoedaphic conditions; 5 - structure characteristics of forest communities. Nor-malized coefficient of interrelation $\mathrm{C}(\mathrm{A} ; \mathrm{B})$ between the geocomponent attributes, bv[57]: $6-0.071-0.100 ; 7-0.101-0.130$; 8 - 0.131-0.160; 9 - 0.161-0.190; $10-0.191-0.220 ; 11-0.221-0.250 ; 12-0.251-0.300 ; 13-0.301-0.440$; $14-0.441-0.720$.

Absolute elevation, litology of bedrockand steepness of slope are initial abiotic factors, whish determine the whole system of space landscape-ecological interrelations. We have used also significant complexabiotic parameter - altitudinal-exposition zonality known as one from forms of dislocation zonality [22]. This parameter accounts the simultaneous influence both of altitude and of solar and circulation expositions.

During the formation of young island-arc volcanic landscapes, the topological structural-functional contrasts encompass the taxonomic norms of soil-biotic characteristics of quite a number of zonal-regional units, which are as though focused on various forms of lowland microrelief(Fig.20). Thus, at the initial stages of subaerial landscape genesis, the local geomorphological conditions create the centers of origin of different phytocoenological and soil structures of a higher (zonal-regional) level. The first cause is the pronounced thermo- and hydroedaphic contrasts formed on local catenas. Such contrasts quite definitely simulate the altitudinal-zonal and expositional differentiation of hydrothermal conditions of forest growth and soil formation. 
Insular-Arc Volcanic Ecosystems as Centres of Forming the New Parts of Continental Biosphere (by the example of South-Kuril Insular Ridge)

Our evaluations for structure organization of forest ecosystems in insular-arc landscape are based on the fundamental concept of global ecology concerning the close relationship between natural zonality and the heat-to-moisture ratio $[14,15,30]$, which was expressed through the Vysotsky-Ivanov's annual atmospheric humidity factor $-F_{\text {hum }}$ (see aquation 4 ).

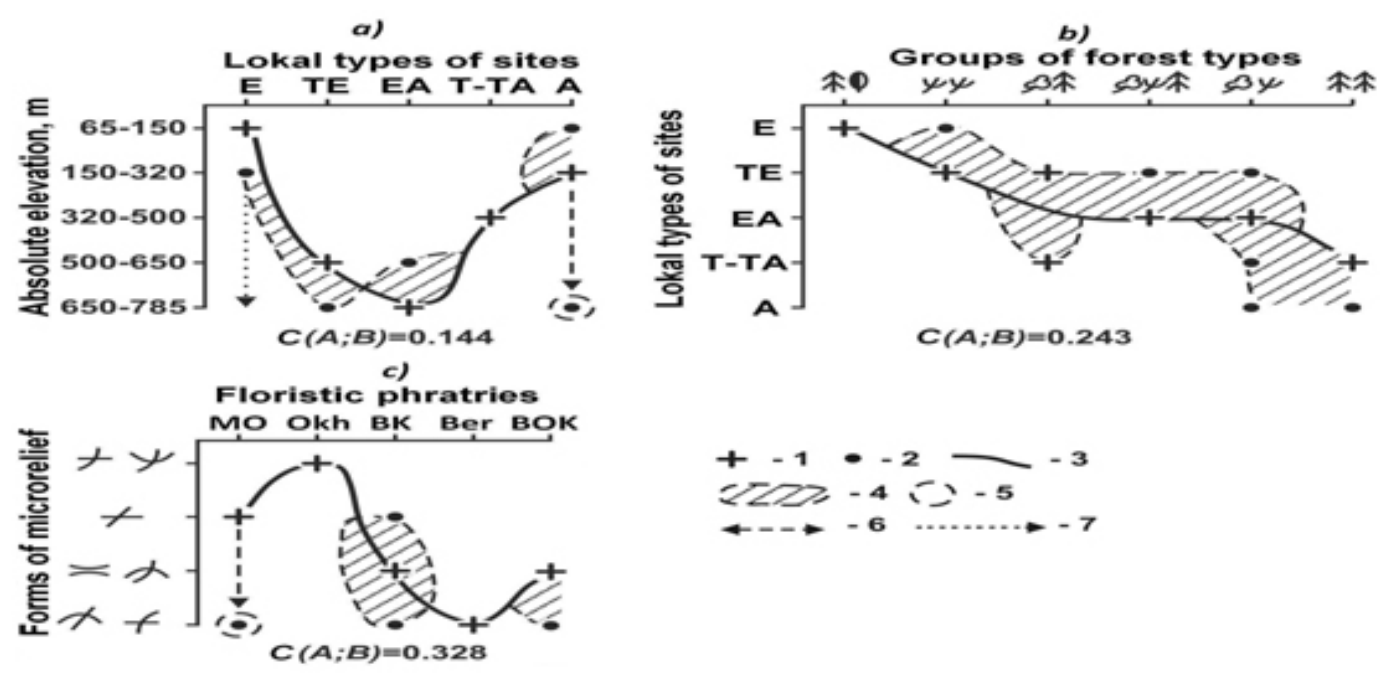

Fig.19. Binary connections for groups of forest types and floristic phratries with absolute eleva-tion, local types of sites and forms of microrelief.

Symbols: 1 - the ecological dominant; 2 - the "fuzzy" part of ecological niche; 3 - the trajec-tory connecting ecological dominants; 4 - the space of ecological niche; 5 - the enclave; 6 - the altitudinal interval of fragmentation of ecological dominants; 7 -the direction of sporadic distri-bution of a phenomenon with the given gradations of a factor. Rest conventional meanings see in the text.

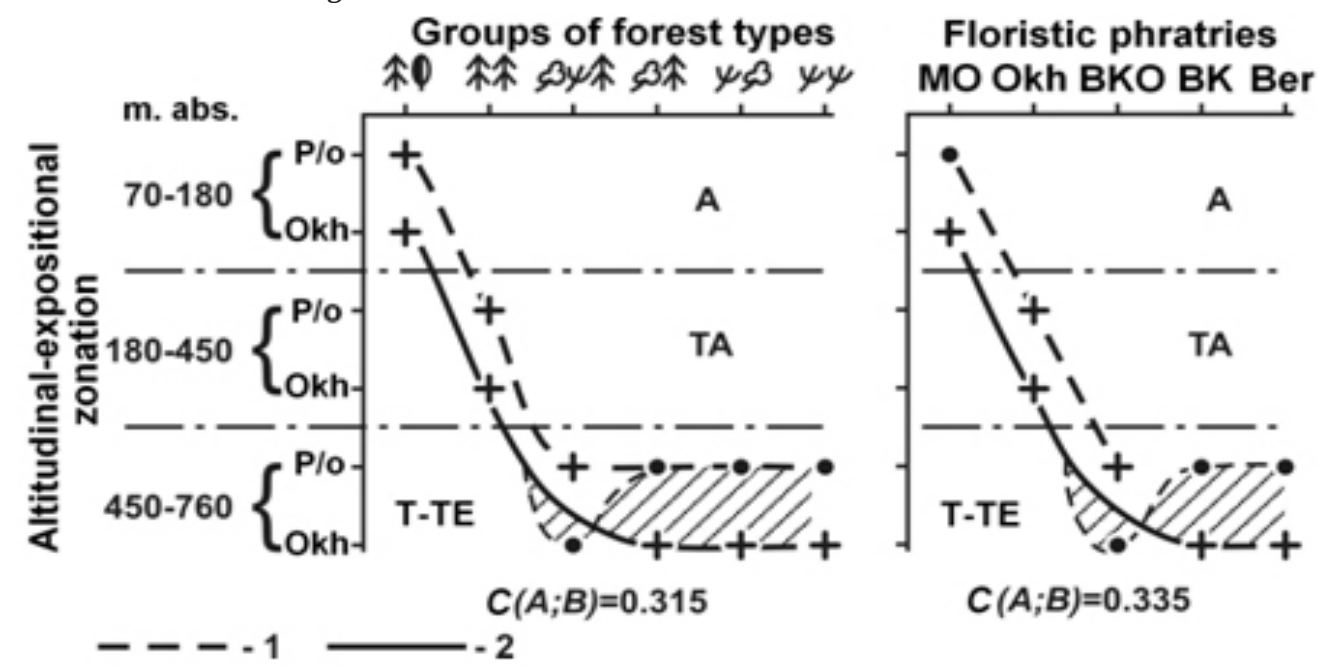

Fig.20. Distribution of groups of forest types and floristic phratries in space of dislocation altitu-dinalexpositional zonation.

Sectors: 1 - Pacific ocean (P/o); 2 - Okhotsk sea (Okh). A, TA, T-TE - types of local sites. Rest conventional meanings are the same as in Fig. 19. 
Insular-Arc Volcanic Ecosystems as Centres of Forming the New Parts of Continental Biosphere (by the example of South-Kuril Insular Ridge)

The humidityfactor is a rather representative index of natural-territorial differentiation in the insular volcanic low mountains (Table 5). In general, the partial effect of solar-circulation exposure is weak, and the basic contribution to moisture content is made by not solar but circulation exposure associated with the sea currents and the monsoon regime. The more sunny NE-SE slopes of the Pacific Ocean sector facing the Kuril-Kamchatka current have the same $F_{\text {hum }}$ as the more shadowy NW-NE slopes of the OkhotskSea sector, where the branch of the warm Kuro-Sio current approaches (the compensatory effect). On piedmont plains, as well as in the lower and middle strata, there are no marked sector contrasts in $F_{\text {hum }}$. The most extensive spatial variations of atmospheric humidification are observed in the lower stratum of the Pacific Ocean sector. On the shadowy NW-NE slopes, $F_{\text {hum }}$ is higher than on the sunny SW-W slopes. At the same time, the dark-coniferous forests of the Mendeleev landscape grow in a sufficiently broad range of solar exposure. The belt of mountain dark-coniferous forests and the birch elfin wood band are formed under the comparatively similar conditions of atmospheric humidification, which gives grounds for considering them as a genetically uniform altitudinal-zonal formation.

Table5. Mendeleev volcano landscape. Taxonomic (average weighted) norms of Vysotsky-Ivanov's annual atmospheric humidity factor peculiar to different floristic phratries and groups of forest types

\begin{tabular}{|c|c|c|}
\hline \multicolumn{2}{|c|}{ Divisions } & Fhum \\
\hline \multirow[t]{5}{*}{ Floristic phratries } & MO & 3.91 \\
\hline & Okh & 4.52 \\
\hline & $\mathrm{Bk}$ & 4.51 \\
\hline & Ber & 5.08 \\
\hline & BKO & 4.90 \\
\hline \multirow[t]{6}{*}{ Goups of forest types } & 來( & 3.86 \\
\hline & 本來 & 4.54 \\
\hline & ફ0ર & 4.08 \\
\hline & $\psi$ & 4.51 \\
\hline & $\psi \psi$ & 5.08 \\
\hline & ఏ્રે杢 & 4.90 \\
\hline
\end{tabular}

Note. Conventional meanings see in the text.

\section{Productivity and Biological Cycle in Forest Insular Ecosystems}

At modeling, the high emphasis was placed on phytocoenotyic functional block - the parameters of annual and perennial cycles of plant matter turnover. It is determined that the shifts in small biological cycle (phytomass production and degradation), in that number including their climatogenic successions, appear as main driving force for evolution transformation of nature ecosystems. These changes take the first several years in the taiga zone and are completed with a year in the subzone of broadleaf forests [43]. 
Insular-Arc Volcanic Ecosystems as Centres of Forming the New Parts of Continental Biosphere (by the example of South-Kuril Insular Ridge)

First of all, the map of total annual production of forest phytocoenosis $\left(P C_{\text {tot }}\right)$ in Mendeleev landscape was constructed (Fig. 20).The map was calculated by L.S. Sharaya bynext regression empirical equation:

$$
\begin{gathered}
P C_{\mathrm{tot}}=-2.613 \cdot t_{30-3.60}-0.4709 \cdot W(20-30)_{-3.18}+0.2784 \cdot G A^{*} \cos \left(A_{0}\right)_{+2.48}+84.07 ; \\
R^{2}=0.364 ; \operatorname{Degr}=16.7 \% ; P<10^{-3} .
\end{gathered}
$$

Here, $t_{30}$ issoiltemperatureforthedepthof30 $\mathrm{cm}\left({ }^{\circ} \mathrm{C}\right), W(20-30)$ - soilmoistureinlayer $20-30 \mathrm{~cm}(\%)$, $G A^{*} \cos \left(A_{0}\right)$ - northern component of slope steepness. Modeldescribes $36 \%\left(R^{2}=0.364\right)$ of space changes for total productivity of forest ecosystems by comparatively low indicator of degradation. Only $t_{30}$ and $W(20-30)$ are statistical significance predictors in this equation. The productivity has a tendency to the decreases if both of soil temperature and of soil moisture rise. Factor $G A^{*} \cos \left(A_{0}\right)$ reflects any increase of productivity on the steep slopes of northern exposition.

The Mendeleev volcanic landscape, along with the Kunashir Island and the entire South-Kuril Range, is a part of the Pacific marginal-continental and island-arc ring, differing from intracontinental territories by the generally higher indices of biological productivity and accumulation of living organic matter [8,9]. Our empirical data are in agreement with these concepts in regard to the boreal and subboreal forests (Table 6). The coniferous/ broadleaved forests of low-plain and piedmont Mendeleev microlandscapes have the reserves of above-ground living phytomass (the taxonomic norm $B L \geq 340$ tons/ha), which are considered maximal for the Pacific Northwest (about 300 tons/ha) and even exceed this maximum. For comparison, let us note that the most productive subboreal (pine-oak-lime) forests of the By-Oka-Terrasebiosphere reserve located in the south of the subtaiga zone of the Russian Plain have a taxonomic norm is $B L=376$ tons/ha, while in the cedar/broadleaved forests of the boreal ecotone in the Lower by-Amur (Priamurye) it hardly reaches the value of 240 tons/ha [44]. The fir/spruce forests of the lower altitude stratum $(250-500 \mathrm{~m})$ by the parameter $B L=215-230$ tons/ha are not inferior to the dark-coniferous forests of Hokkaido, Sakhalin and Primorye with $B L$ values varying from 130-150 to $230-280$ tons/ha [8].

Table6. The taxonomic norms of phytomass, productivity, and complex parameters of the biological cycle (CPBC)

\begin{tabular}{|c|c|c|c|c|c|c|}
\hline \multirow{2}{*}{$\begin{array}{c}\text { Phytomass, } \\
\text { productivity, } \\
\text { CPBC }{ }^{*} \text { ) }\end{array}$} & \multicolumn{6}{|c|}{ Groups of forest types } \\
\hline & $\begin{array}{l}\text { CB } \\
\text { 木中 }\end{array}$ & $\begin{array}{l}\text { DC } \\
\text { 林 }\end{array}$ & $\begin{array}{l}\mathrm{SbS} \\
\text { §人爪木 }\end{array}$ & $\begin{array}{l}\mathrm{SbCe} \\
\boldsymbol{\psi}, \boldsymbol{B}\end{array}$ & $\begin{array}{l}\text { CeW } \\
\psi \psi\end{array}$ & $\begin{array}{l}\text { CeSbS } \\
\text { ఏ્భ }\end{array}$ \\
\hline$B L$ & 340.70 & 223.75 & 163.60 & 89.59 & 89.70 & 135.00 \\
\hline$P G$ & 11.16 & 14.95 & 11.75 & 8.62 & 4.18 & 14.19 \\
\hline PStr-shr & 9.52 & 8.14 & 5.72 & 3.81 & 3.16 & 3.86 \\
\hline PVtr-shr & 3.99 & 3.21 & 2.41 & 1.83 & 1.62 & 1.94 \\
\hline PStr-shr & $13 . .51$ & $11 . .36$ & 8.13 & 5.64 & 4.78 & 5.00 \\
\hline PVtot & 15.15 & 18.16 & 14.16 & 10.45 & 5.80 & 16.13 \\
\hline PCtot & 24.67 & 26.31 & $19 . .88$ & 14.26 & 8.96 & 20.00 \\
\hline$K R$ & 0.044 & 0.036 & 0.087 & 0.117 & 0.065 & 0.119 \\
\hline$K A$ & 0.467 & 0.536 & 0.520 & 0.523 & 0.488 & 0.566 \\
\hline$K Y$ & 1.68 & 0.54 & 1.31 & 0.46 & 5.95 & 0.46 \\
\hline
\end{tabular}
in the groups of forest types of the Mendeleev volcanic landscape

*) Convention meaning see in the text.

American Research Journal of Earth Science

Page 34 
The annual production of the phytobiota has still higher values. Let us emphasize the altogether phenomenally high productivity of south Kunashir coniferous-broadleaf and fir/spruce forests. The taxonomic norm is $P C_{\text {tot }}>$ 24-26 tons/ha·yr (Table 4), with the maximum values up to 5-40 tons/ha·yr. This normal value exceeds the productivity of temperate coniferous and mixed forests of the Primorye, Manchuria and Northeastern China, with total production within a range of 11-18 tons/ha·yr, rarely reaching 21-24 tons/ha·yr. In the south taiga of West and East Siberia, these values are 2.5-7.1 tons/ha·yr [9]. In the coniferous/broadleaved forests of the Lower Priamurye, the mean values are $P C_{\mathrm{vol}}=8.5-9$ tons/ha per year in the boreal ecotone of the VolgaRiver basin: about 11-12 tons/ha·yr. The productivity values similar to South Kunashir (from 7-10 to 20-25 tons/ ha.yr on average) are observed only in the broadleaved and coniferous forests of Honshu and Hokkaido [8].

Thus, the maximal biomass production "programmed" by the developmental strategy of plant communities [84] in the forest landscapes of insular Neo-Pacific is much more marked than in their zonal analogs on the neighboring continent. In other words, the boreal forests of the Mendeleev volcanic landscape, in contrast to the analogous forests of Priamurye and Primorye, have more and less marked properties of patience and violence, respectively, according to L.G. Ramensky [74]. As regards structure and function, terrestrial ecosystems of the Pacific Fire Ring are “... a particular class of aggregates of natural formations" [8,p. 208).

The implementation of the principle of maximal productivity, i.e., attainment of the maximum efficiency of phytocoenosis, is possible only under favorable conditions of the abiotic environment. This fact per se contradicts the widespread concept of existence of zonal types of plant formations on the northwestern Pacific islands with very limited heat and energy resources. Then, there must be a harmonic combination of photosynthetic and respiration functions for a plant community to reach the maximum productivity [87]. Judging by the productivity values presented above, it would be right to suggest the presence of quite optimal functional interrelationships of forest communities in the Mendeleev volcanic landscape. Accordingly, we can assume that these "climatically unjustified" terrestrial phytocoenoses (see below) have rather high level of adaptation to the conditions of extraordinary oceanic environment. It ensures their survival and increases their capacity for evolutionary transformations. As is known $[6,86,99]$, adaptation underlies all forms of ecosystem evolution, and this mechanism has invariably worked in the critical epochs of history of the biosphere [16].

There are the two main characteristics of distribution of above-ground living phytomass reserves and forest productivity in the Mendeleev landscape (Fig.21):

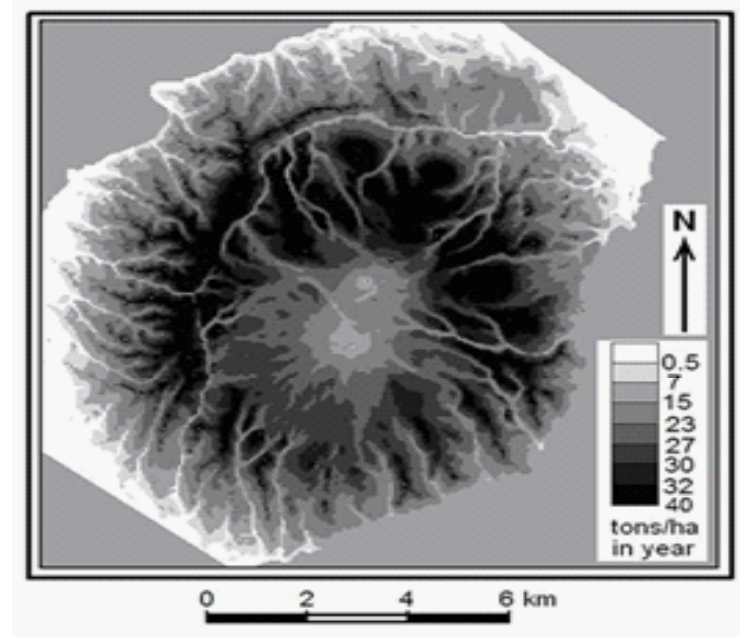

Fig21. The raster map of total productivity of mixed and dark-coniferous forests, stone birch crooked forests and cedar elfin woods of the Mendeleev volcanic landscape. Calculated and plotted by L.S. Sharaya. 
Insular-Arc Volcanic Ecosystems as Centres of Forming the New Parts of Continental Biosphere (by the example of South-Kuril Insular Ridge)

(1) the general decrease in these values with true altitude and (2) the dominance of the Okhotsk Sea sector over the Pacific one by the altitudinal-zonal values of $B L$ and $P C_{\text {vol }}$. The former phenomenon can be logically explained by bioclimatic altitudinal zonality, while the latter seems to have more complex causal mechanisms. Here we can observe both the above-described circulation-exposure zonality, which is most favorable for the phytobiota of the OkhotskSea sector, and the influence of volcanic geotherms on edaphotops, which is predominant in the same sector.

The subboreal and boreal forests of a young volcanogenic Neo-Pacific landscape dramatically differ from their zonal intracontinental analogs not only in total phytomass and productivity values but also in production process structure per se (Fig.22). The production of ground cover green mass $(P G)$ is especially high on volcanic islands, with a considerable amount of tall grasses and Kuril bamboo thicket. In south Kunashir coniferous/ broadleaved forests, the taxonomic norm of herbage green mass production $(P G)$ is more than 11.0 tons/ha.yr, with a maximum up to 28.0 tons/ha·yr. It makes up about $44 \%$ of total above-ground phytomass produced, while the tree and shrub skeletal mass production $\left(P S_{\text {tr-shr }}\right)$ is no more than $40 \%$. Dark-coniferous forests are characterized by a still greater gap between these parameters (61\% vs. $32 \%)$. In general, the portion of photosynthesizing green mass in boreal and subboreal forests of the Mendeleev landscape is $60-70 \%$ of the total above-ground productivity.

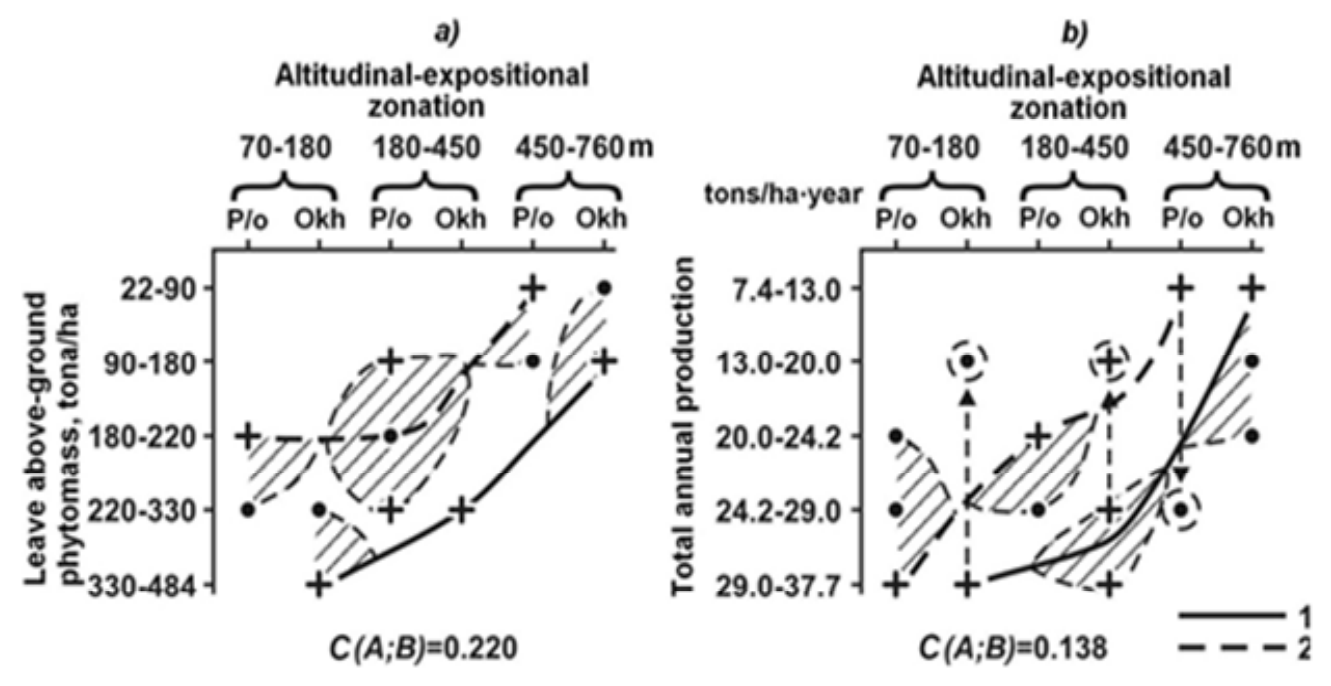

Fig22. The distribution of phytomass reserves and forest productivity by three steps of true alti-tudes in the Okhotsk Sea (1) and Pacific Ocean (2) sectors of the Mendeleev landscape.

Symbols are the same as in Fig. 19.

By comparison, the middle and maximum $P G$ values are within a range of $0.5-1.3$ and up to 3.4 tons/ha·yr, respectively, in the marginal-continental Lower Priamurye vs. 5.5-7.5 and up to 10.5 tons/ha'yr, respectively, in the intracontinental By-Oka-Terrasebiosphere reserve. At the same time, the portion of total green mass is drastically reduced: from $33-36 \%$ to $42-47 \%$ in the former case and from $38-40 \%$ to $46-49 \%$ in the latter case, reaching $61 \%$ only in the pine-lime-oak forests.

As we can see, the autotrophic biogenesis in subboreal and boreal forests at the initial, island-arc stage of subaerial landscape genesis is directed mainly at production of green photosynthesizing mass that annually becomes tree waste. It gives an impetus to substantial acceleration of the biological cycle as a factor of functional stability of forest biogeocoenosis, which is confirmed by the values of complex parameters of 
Insular-Arc Volcanic Ecosystems as Centres of Forming the New Parts of Continental Biosphere (by the example of South-Kuril Insular Ridge)

metabolism (see Table 6). The subboreal and boreal forests of the Mendeleev insular landscape have rather high values of the annual turnover of above-ground organic matter (normally, $C R=0.044-0.036$ ). The normal values of this parameter in analogous forest biogeocoenoses are $0.023-0.040$ in the marginal-continental Lower Priamurye and only 0.017-0.030 in the boreal ecotone of the Middle Povolzhye. Compared to the East European boreal ecotone, the rate of phytomass turnover increases by $35-40 \%$ in south Kunashir coniferous/ broadleaved forests and by $40-50 \%$ in dark-coniferous forests.

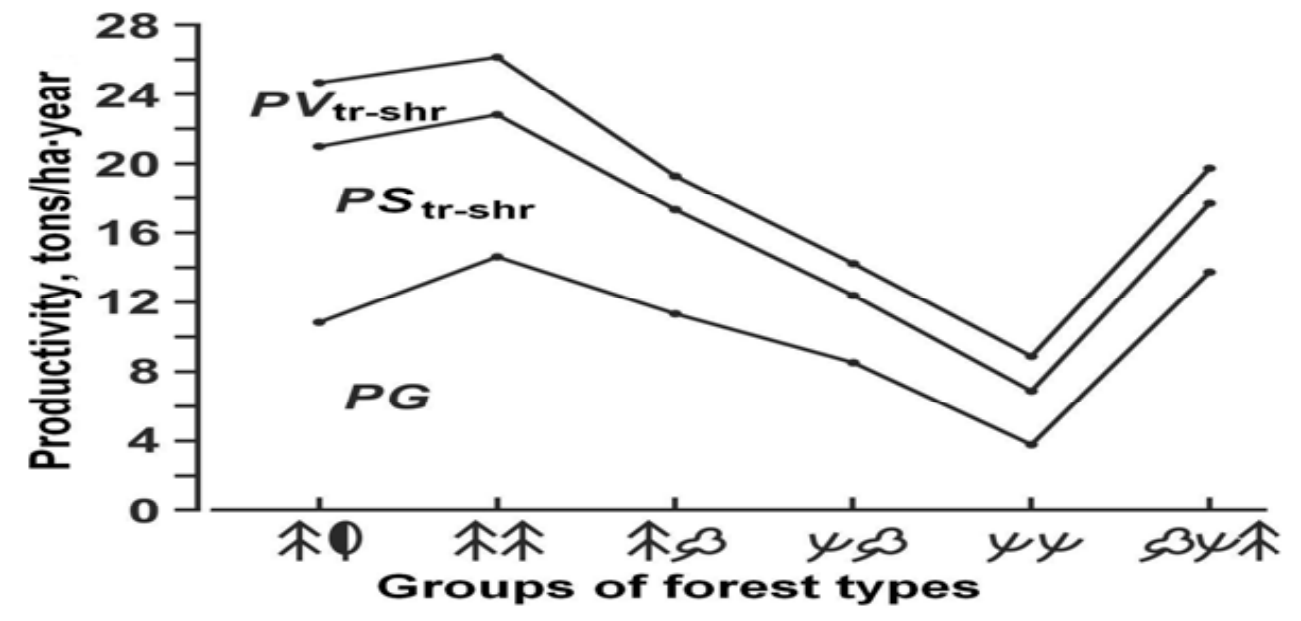

Fig23. Distribution of the productivity of ground cover green mass (PG), tree and shrub skeletal mass (PStr-shr), tree and shrub green mass (PVtr-shr) in different groups of forest types.

The litter/tree-waste index $C Y$, which is known [20] to be the major conductive channel for metabolic processes in a forest ecosystem, is also very representative. The boreal and subboreal forests of the Mendeleev landscape substantially differ from their intracontinental analogs in a much more optimal ratio between the income and consumption of dead organic matter in forest litter, which is demonstrated by the relatively low values of the $C Y$ parameter (the taxonomically normal values of $0.21-0.44$ to $1.68-2.08$ years vs. $6.42-7.95$ years, e.g., in the By-Oka-Terrasebiosphere reserve). The capacity of this channel increases 1.7-2 times in subboreal forests and 8-10 times in boreal forests. The marginal-continental Lower Priamurye is much closer to South Kunashir by the above values of the biological cycle, though it is also weaker here.

Thus, extrazonal, i.e., going beyond the limits of intracontinental zonal norms, productivity and biological cycle indices in the subboreal and boreal belts of young island-arc landscapes demonstrate the highly effective work of their soil-biotic core. Intensification of metabolism is aimed at providing the functional stability and structural development of forest communities in the generally cold oceanic climate of Northwestern Pacific, which is extremely unfavorable for forest formation. Hence, the living above-ground phytomass can reach the values that approach the maximum in western intracontinental ecoregions. Such is, apparently, one of the most important regularities of the regional functional organization of forest cover at the initial, island-arc stage of subaerial landscape genesis.

\section{CONCLUSION}

Given presentation is the results of research into the spatial organization of island-arkecosystems in the Pacific Mobile Belt as a focus of evolutionary ecological and geographical processes and phenomena at the modern stage of development of the biosphere. This trend of complex physical geography has been put forward previously by the author as a conceptual idea $[41,42]$. The problem of studying the organization of biogeocoenotic systems 
Insular-Arc Volcanic Ecosystems as Centres of Forming the New Parts of Continental Biosphere (by the example of South-Kuril Insular Ridge)

of insular land in the tectonically and climatically active zone of contact between the ocean and the continent is set forth. The proposed statements are factually substantiated on the basis of the known bioclimatic, as well as the results of large-scale landscape-ecological surveys performed at experimental sites in the insular-arc sectors of the Pacific Ocean mega ecotone of North-West Eurasia. Hence, it was possible to saturate the concept with particular contents and to develop its fundamental theoretical and methodological aspects on the basis of empirical-statistical modeling.

The two most important features of this regional bioclimatic system have been established: (1) the simultaneous reduction and compression (compared to the neighboring continent) of the entire spectrum of altitudinal zonality, which is almost completely (from the forest belts to the subgoltsy belt) falls within the low-mountain layer of macrorelief and (2) the coverage by local structural-functional contrasts of the taxonomic norms of the soil-biotic characteristics of quite a number of superior zonal-regional units.

The empirical statistical models of the island-arc stage of continental biosphere development in the North-West Pacific have been created by the example of experimental testingarea in vicinity of the active Mendeleev Volcano on the Kunashir Island (the South Kuril Ridge). It was shown that on this stage local geomorphological conditions created the centers of origin of diverse phytocoenological and soil structures of the higher (zonal-regional) levelat the initial stages of continental biosphere development.

The following two phenomena of structural-functional organization of the Mendeleev volcanic landscape have been revealed. First, there is an exceptionally high system-forming role of forest phytobiota in the formation and development of young volcanic landscapes. The forest communities of insular Neo-Pacific in the south of the boreal belt are characterized by the annual turnover of plant matter falling into the category of intensive metabolism and being typical only of subtropical forests by the zonal standards. Then, the intensive annual turnover of above-ground phytobiota and the high rate of the entire biological cycle in South Kunashir landscapes are the main factors of their stability under the conditions of relatively low temperatures and, together with magmatic geotherms (see below), contribute to the formation of subboreal "climatically unjustified" forests. It is the second phenomenon of organization of forest ecosystems at the initial, insular-arc stage of subaeral landscape genesis. Here, one cannot but see the emergence of progressive evolutionary tendencies in buffer forest communities, so typical of the Pacific Ocean mega ecotone of Northern Eurasia. The known proposition of evolutionary theory of the biosphere [81] has been confirmed, stating that the enhanced intensity of biogeocoenoses and the improvement of biological cycles underlie evolutionary progress and are the main contents of evolution. Such evolutionary tendencies in plant cover emerge already at the initial, volcanogenic stage of formation of the continental biosphere.

\section{REFERENCES}

1. Abdurakhmanov, A.I., Razzhigaeva, N.G., Rybkin, A.V., et al. (2004). Vulkan Mendele-eva - istoriua razvitiya i sovremennoe sostoyanie (o. Kunashir, Kurilyskie osnrova) // Vpaimosvyasy mezhdu nektonikoy, seysmichnostyu, magmoobrazovaniem i izverzheni vulkanov. Petropavlovsk-Kamchatsky: Kamcht. nauch. tsentr RAN. P. 45-47 (in Russian).

2. Allen, D.M. (1974)The relationship between variable selection and data augmentation and a method for prediction. Technometrics.Vol. 16.P. 125-127.

3. Alisov, B.P. Klimat SSSR (1956). Moskva: Izd-vo MGU (in Russian).

4. Alisov, B.P., Poltoraus, B.V. (1974)/ Klimatologiya. Moskva: Izd-vo MGU (in Russian).

5. Aprodov, V.A. (1982). Vulkany. Moskva: Mysly (inRussoan). 
Insular-Arc Volcanic Ecosystems as Centres of Forming the New Parts of Continental Biosphere (by the example of South-Kuril Insular Ridge)

6. Ashby, W. R. (1956). An Introduction to Cybernetics. London: Oxford University Press.

7. Avdeyko, G.P., Popruzhenko, S.V., Palueva, A.A. (2001). Sovremennaya tektonicheskaya struktura KurilyskoKamchatskogo hegiona i usloviya magmoobrazovaniya // Geodinamika I vulkanizm Kurilo-Kamchatskoy ostrovoduzhnoy sistemy. Petropavlovsk-Kam-chatsky: In-t vulkanich. geologii i geokhimii RAN. P. 9-33 (in Russian).

8. Bazilevich, N.I. (1981). Produktivnosty, energetika i biogeokhimiya nazemnyh ekosistem Tihookeanskogo kolytsa (Productivity, power engineering and biogeochemistry of terrestrial ecosystens of Pacific Ocean ring). Voprosy geografii. Sb. 117. Moskva: Mysly (in Russian).

9. Bazilevich, N.I., Grebenshchikov, O.S., Tishkov, A.A. (1986) Geographicheskie zakonomernosti struktury i funktsionirovaniya ecosystem (Geographical conformities to natural laws of ecosystem structure and functioning). Moskva: Nauka (in Russian).

10. Bazilevich, N.I., Titlyanova, A.A. (2008). Biologichesky krugovorot na pyati kontinentah: azot i zolynye elementy v prirodnyh nazemnyh ekosistemah (Biological cycle at five continents). Novosibirsk: Izd-vo SO RAN (in Russan).

11. Begon, M., Harper, J.L., Towensend, C.R. (1989). Ecology: Individuals, Populations and Communities. Vol. 2. Oxford-London-Edinburg: Blackwell Sci. Publications.

12. Bezrukov, P.L., Zenkevich, N.L., Kanaev, V.Ph., Elbytsev, G.B. (1958). Podvodnye gory i vulkany Kurilyskoy ostrovnoy gryady // Trudy Lab. Vulkanologii. Vyp. 13. Moskva: Izd-vo AN SSSR. P. 71-88 (in Russian).

13. Braitseva, O.A., Melekestsev, I.V., Erlikh, E.N. (1974) Noveyshaya vulkanicheskaya deyatelynosty, Kamchatka, Kurilyskie i Komandorskie ostrova // I.V. Luchitsky, (Ed.). Istorya razvitiya relyefa Sibiri i Dalynego Vostoka, Moskva: Nauka. P. 369-394 (in Russian).

14. Budyko, M.I. (1971). Klimat i zhizny (Climate and live). Leningrad: Gidrometeoizdat (in Rassian).

15. Budyko, M.I. (1977). Globalynaya ekologiya (Global ecology). Moskva: Mysly (in Russian).

16. Budyko M.I. (1984). Evolutsiya biosphery. Leningrad: Gidrometeoizdat (in Russian).

17. Chudaev, O.V., Chudaeva, V.A. (2009). Sostav i genesis gidritermalynyh system oblasteqy sovremennogo vulkanizma // Vestnik DVO RAN. No 4. P. 24-29.

18. Droznin, V.A., Dubrovskaya, I.K., Kiryukhin, A.V. (2004) Diagnostika geotermaly-nogo rezervuara Avachinskogo vulkana po fumarolynoy aktivnosti i seysmologicheskim dannym // Vzaimosvyasi mezhdu nektonikoy, seysmich-nostyu, magmoobrazovaniem i iz-verzheniyami vulkanov v vulkanicheskih dugah. PenropavlovskKamchatsky. P. 37-39 (in Russian).

19. Dyakonov, K.N., Puzachenko, Yu. G. (2005). Teoreticheskie voprosy ostrovnogo landshaftiovedeniya // Gorizonty geographii. K 100-letiyu K.K. Merkova. Moskva: Geographich. fakulytet MGU. P. 14-17 (in Russian).

20. Dylis, N.V. (1978). Osnovy biogeotsenologii (Fundamentals of biogeocoenology). Moskva: Izd-vo MGU (in Russian).

21. Ganzey, K.S. (2010). Landshaphty i phiziko-geographicheskoe rayonirovanie Kurilyskih ostrovov. Vladivostok: Dalynauka (in Russian).

22. Gartsman, I.N. (1971). Problemy geographicheskoy zonalynosti i diskretnosty gidgometeorologicheskih poley v gornyh usloviyah mussonnogo klimata // Trudy DVNIGMI. Vyp. 35.P. 3-31 (in Russan). 
Insular-Arc Volcanic Ecosystems as Centres of Forming the New Parts of Continental Biosphere (by the example of South-Kuril Insular Ridge)

23. Gerasimov, I.P. (1986). Problemy globalynoy geomorphologii. Moskva: Nauka )in Russian)

24. Gerasimov, I.P., Bravar, I., Dresh, Zh. (1980). Alypy- Kavkaz. Sovremennye problemy konstruktivnoy geographii gornyh stran. Moskva: nauka (in Ruaaian).

25. Glazovskaya, M.A. (1988). Geokhimiya prirodnyh i antropogennyh landshaftov SSSR (Geochemistry of nature and anthropogenic landscape of USSR). Moskva: Vysshaya shkola (in Russian).

26. Gorshkov, G.S. (1958). Deystvuyushchie vulkany Kurilyskoy dugi (Volcanic activity of Kuril arc). Trudy Laboratorii vulkanologii, Vol.13. Moskva: Izd-vo AN SSSR. P. 5-70 (in Russian).

27. Gorshkov, G.S. (1967). Vulkanizm Kurylyskoy ostrovnoy dugi (Volcanism of Kuril insular arc). Moskva: Nauka (in Russian).

28. Grabkov, V.K., Khudyakov, G.I. (1993). Vulkanicheskie lanshafty i phiziko-geogra-ficheskoe rayoniriovanie Kurilyskih ostrovov // Issledovaniu i konstriurovanie landshaftov Dalynego vostoka i Sibiri. Vladivostok. P. 28-47 (in Russian).

29. Grabkov, V.K., Alekseeva, L.M., Kapustyan, A.L. (1986). Vysotnoe raspredelenie rastitelynosti na khrebte Dokuchaeva (gory Morozova, Gerasimova i Phregat) // Botanich. zhurnal. Tom 71, No 10.P. 1389-1397 (in Russian).

30. Grigoryev, A.A. (1966). Zakonomernosti stroeniya i razvitiya geographicheskoy sredy (Conformities to natural lows of struvture and development of geographical environment). Moskva: Mysly (in Russian).

31. Guebler A. (1931-1932). Die Kurilen. Ein geographisch-enthnographischer Beitrag // Geographischethnogrephischen Gesellschaft in Zürich. Bd. XXXII. P. 1-104.

32. Haggett, P. (1975). Geography: A Modern Synthesis. Second Edition. New York, London: Harper Internat. Edition.

33. Hijmans R.J., Cameron S.E., Parra J.L., Jones P.J., Jarvis A.(2005). Very high resolution interpolated climate surfaces for global land areas // International Journal of Climatology, Vol. 25, No.15.P. 1965-1978.

34. Hutchinson G.E. (1957). Concluding remarks // Cold Spring Harbor Symposia on Quantitative Biology. Vol. 22.P. 415-427.

35. Isachenko, A.G. (1985). Landshafty SSSR. Leningrad: Izd-vo LGU (in Russian).

36. Isachenko, A.G. (1988). Sistema landshaftov i soderzhanie landshaftnoy karty Mira // Izvestiya Vsesoyuz. geogr. ob-va. T. 120, Vyp. 6.P. 489-501 (in Russian).

37. Ivanov, A.N. (2005). Landshaftnye osobennosti ostrovov Severo-Zapadnoy Patsifiki. Izvestiya RGO, Vol.141, Vyp. 4.P. 4-11 (in Russian).

38. Ivanov, A.N. (2014). Problemy ostrovnogo landshaftovedeniya (Problems of island landscape study). Voprosy geographii, Vyp. 138, Gorizonty landshaftovedeniya. Moskva: “Kodex”. P. 138-158 (in Russian).

39. Ivanov, N.I. (1958). Atmosfernoe uvlazhnenie tropicheskih i sopredwlynyh stran Zemnogo Shara // Zapiski Geogr. Obshchestva Soyuza SSR. Tom 18. Novaya seriya. Moskva-Leningrad: Id-vo AN SSSR (in Russian).

40. Kolesnikov, B.P. (1961). Rastitelynosty // Dalyniy Vostok. Phiziko-geographicheskaya kharakteristika. Moskva: Izd-vo AN SSSR. P. 183-245 (in Russian).

41. Kolomyts, E.G. (1987) Landshaftnye issledovaniya v perekhodnyh zonah (Landscape research in transitional zanes). Moskva: Nauka (in Russian). 
Insular-Arc Volcanic Ecosystems as Centres of Forming the New Parts of Continental Biosphere (by the example of South-Kuril Insular Ridge)

42. Kolomyts, E.G. (1988). Ecoton kak ob'ekt phisiko-geographicheskogo issledovaniya // Izvestiya AN SSSR. Seriya geographich. No 5.P. 24-36 (in Russian).

43. Kolomyts, E.G. (2012). Forest ecosystems and global climate changes (Experience of predictive modeling. Saarbrücken, Germany: LAP LAMBERT Acad. Publishing GmbH \& Co. Kg.

44. Kolomyts, E.G. (2015). Pacific ocean Mega ecotone of Nortehern Eurasia as evolutionary model of continental biosphere // Journ. of Global Ecology and Environment. Vol. 2 [Issue 2].P. 90-115.

45. Korsunskaya, G.V.(1958) Kurilyskaya ostrovnaya duga (phiziko-geographichesky ocherk). Mosklva: Geographgiz (in Russian).

46. Kotlyakov, V.M., Baklanov, P.Y.a. \& Komedchikov, N. N. (Eds.), (2009). Atlas Kurilyskih ostrovov (Atlasfor Kuril islands). Moskva-Vladivostok: IPTS “DIK” (in Russian).

47. Kozlov, D.N., Zharkov, R.V. (2012) Teplovizionnaya syomka aktivnyh vulkanov Kurilyskih ostrovov v 2009-2011 gg. // Vestnik KRAUNTS, Nauki o Zemle, Vol. 1 No 19.P. 1-7 (in Russian).

48. Krestov, P. V. (2006). Rastitelyny pokrov i phitogeographicheskie linii Severnoy Patsifiki (Vegetationcover and phytogeographical lines in Northern Pacific). Vladivostok: Biologo-pochvenny institut DVO RAN (in Russian).

49. Krishtofovich, A.N. (1946). Evolutsiya rastitelynogo pokrova v geologicheskom proshlom i eyo osnovnye factory (Evolution of plant cover in the geological past and its main factors). In V.L. Komarov (Ed.). Materialy po istorii flory i rastitelynosty SSSR. Vyp. II, Moskva-Leningrad, Izd-vo AN SSSR. P. 21-87 (in Russian).

50. Kustler, G. (1957). ABC of information theory. In Hubert P. Yockey (Ed.) Information Theory in Biology. LondonNew York-Los Angeles: Pergamon Press.P. 5-48.

51. Lappo, S.S., Lebedev, V.L., (2005). Geographicheskaya zonalynosty v vodah Mirovogo Okeana // Gorizonty geographii. K 100-letiyu K.K. Markova. Moskva: geogr. fakulytet MGU. P. 230-237 (in Russian).

52. Lashkov, A.N. (1948) K morphologii pochv Yuzhnyh Kurilyskih ostrovov. Izvestiya Vsesoyuz. georg, ob-va. Vol. 80, No1.P. 61-68 (in Russian).

53. Letnikov, Ph.A. (2000). Phlyuidny rezhim endogennyh protsessov v kontinentalynoy lithosphere i problemy metallogenii. In D.V. Rundkvist,(Ed.). Problemy globalynoy geodinamiki, Moskva: GEOS. P 204-224 (in Russian).

54. Maksimova, V,Ph. (1982). Phitoindikatsiya v sisteme ocean-materik // Teoreticheskie i prikladnye voprosy biogeographii. Moskva: Nauka (in Russian).

55. Manyko, Yu.I., Rozenberg, V.A. (1970). Vysotnaya poyasnosty rastitelynosti navulkane Mendeleeva. Bioljgicheskie Resursy o-va Sakhalin i Kurilyskih ostrovov, Vladivostok: Biologo-pochvenny institut DVNTS AN SSSR. P. 65-71 (in Russian).

56. Markhinin, E.K. (1956). Vulkan Mendeleeva I yego sostoyanie letom 1954 g. // Byulleteny Vulkanologich. Stantsii. № 24. Moskva: Izd-voANSSSR. P. 33-38 (inRussian).

57. Markhinin, E.K. (1980). Vulkany i zhizny (Problemy biovulkanologii). Moskva: Mysly (in Russian).

58. Markov, K.K., (Ed.), (1980). Phizicheskaya geographiya Mirovogo Okeana (Physical geography of World Ocean). Moskva: Nauka (in Russian).

59. Martynov, Yu.A., Rybin, A.V., Drily, S.I., Martynov, A.Yu. (2009). Zony anomalynogo vulkanizma Kurilyskih ostrovov, ostrov Paramushir // Vestnik DVO RAN. No 4. P. 17-23 (in Russian). 
Insular-Arc Volcanic Ecosystems as Centres of Forming the New Parts of Continental Biosphere (by the example of South-Kuril Insular Ridge)

60. Melekestsev, I.V. (1980). Vulkanizm i relyefoobrazovanie. Moskva: Nauka (in Russian).

61. Melekestsev, I.V., Braytseva, O.A., Ponomareva, V.V. (2001). Novy podkhod k opredeleniuy ponyatiya "deystvuyushchy vulkan" // Geodinamika i vulkanizm Kurilo-Kamchatskoy ostrovoduzhnoy sistemy. Petropavlovsk-Kamchatsky: In-t vylkaubcheskoy geologii i geokhimii RAN. P. 191-203 (in Russian).

62. Mukha, D.E. (2007). Vliyanie vulkanizma na prirodu Kamchatki // Geographicheskie i geoekologicheskie issledovaniya na Dalynem Vostoke. Vyp. 3. Vladivostok: Dalynauka. P. 86-88 (in Russian).

63. Nikolyskaya VV, Khomentovsky AS, (Eds.), (1967). Yuzhnaya chasty Dalynego Vostoka (Southern Part of Far East). Moskva: Izd-vo AN SSSR (in Russian).

64. Odum Eu.P. (1971). Fundamentals of Ecology. Third edition. Philadelphia-London-Toromto: W.B. Saunders Company.

65. Odum, Eu.P.(1983). Basic Ecology. Philadelphia, CBS College Publishing, USA.

66. Panfilov, V.D. (2005). Tsentry evolyutsii i istoricheskie migratsii bioty Zemnogo Shara. Nauchny dnevnik (Evolutionary centers and history migrations of biota of Earth Ball), Moscow: Inst. of Geography RAS (in Russian).

67. Phedotov, S.A. (1991). 0 mekhanizme vylkanicheskoy deyatelynosti na Kamchatke, Kurilo-Kamchatskoy duge i v skhodnyh strukturah // Deystvuyushchie vukkany Kamchatki. T. 1. Moskva: Nauka. P. 18-29 (inRussian).

68. Perelman, A.I. (1975). Geokhimiya landshaphtov (Landscape geochemistry). Moskva: Vysshaya shkola (in Russian).

69. Pianka E.R. (1978). Evolutionary ecology. Second Edition. New York, Hagerstown, San Francisco, London: Harper and Row, Publishers.

70. Pietsch1 T.W., Bogatov V.V., Amaoka K., et al. (2003). Biodiversity and biogeography of the islands of the Kuril Archipelago // Journ. of Biogeogr. Vol. 30.P. 1297-1310.

71. Polynov, B.B. (1956). Izbrannye trudy (Selected works). Moskva: Izd-vo AN SSSR (in Russian).

72. Popov, N.A. (1963). Lesa Yuzhnyh Kurilyskih ostrovov i perspektivy ikh ispolyzovaniya. Trudy konferentsii. Krasnoyarsk: In-t lesa i drevesiny SO AN SSSR. P. 59-69 (in Russian).

73. Puzachenko, Yu.G., Skulkin, V.S. (1981). Struktyra rastitelnosti lesnoy zony SSSR. Sistemny analiz (Structure of forest zone vegetation for USSR). Moskva: Nauka (in Russian).

74. Ramensky, L.G. (1971). Izbrannye raboty (Selected works). Problemy i metody izucheniya rastitelnogo pokrova (Selected Works. Problems and Methods of Studying Vegetation Cover). Leningrad: Nauka (in Russian).

75. Razzhugaeva, N.G., Ganzey, K.A., Mokhova, L.M., Pshenichnikova, N.Ph. (2011). Lygo-vye landshafty Yuzhnyh Kuril: proiskhozhdenie, vozrast i razvitie // Geographiya i prirodnye resursy. No 3. P. 96-104 (in Russian).

76. Rice, R.L. (1978). Fundamentals of Geomorphology, London: Lester university.

77. Ricklefs R.E. (1976). The Economy of Nature. A Textbook in basic ecology. Univers. Pensilvaniya, Portland, Oregon: Chiron Press.

78. Rozen, R. (1969). Printsip optimalnosti v biologii. Moskva: Mir (in Russian).

79. Shmalgauzen, I.I. (1968). Keberneticheskie voprosy biologii. Novosibirsk: Nauka (in Russian).

80. Shmalgauzen, I.I. (1969)/ Problemt darvinizma. Leningrad, Nauka (in Russian).

81. Shwarts, S,S, (1973). Evolutsiya i biosphera // Lavrenko, E.M., Rabotniov, T.A. (Eds.). Problemt biogeotsenologii. Moskva: Nauka.P. 213-228 (in Russian). 
Insular-Arc Volcanic Ecosystems as Centres of Forming the New Parts of Continental Biosphere (by the example of South-Kuril Insular Ridge)

82. Sochava, V.B. (1963). Opredelenie nekotoryh ponyatiy i terminov phizicheskoy geographii // Doklady In-ta geographii Sibiri i Dalynego Vostoka. Vyp. 3. Irkutsk. P. 50-59 (inRussian)

83. Sochava, V.B. (1979). Rastitelyny pokrov na tematicheskih kafrtah. Novosibirsk; Hauka, 1979 (in Russian).

84. Sochava, V.B. (1980). Geographicheskie aspekty sibirskoy taygi (Geographical aspects of Siberian taiga). Novosibirsk: Nauka (in Russian).

85. Sochava, V.B., Bayborodin, V.N. (Eds.). (1977). Korrelyatsionnaya ekologo-phito-tsenoticheskaya karta Aziatskoy Rossii/., M-b 1:7500000. Irkutsk: In-t geographii Sibiri i Dalynego Vostoka SO AN SSSR (in Russian).

86. Timofeev-Resovsky, N.V., Vorontsov, N.N., Yablokov, A.V. (1969). Kratky ocherk teorii evolyutsii (Short sketch of evolutionary theory). Moskva: Nauka (in Russian).

87. Tooming, Kh.G. (1984). Ecologicheskie printsipy maksimalynoy produktivnosti posevov. Leningrag: Gidrometeoizdat (in Russian).

88. Urusov, V.M. (1988). Genezis rastitelynosti i ratsionalynoe prirodopolyzov-anie na Dalynem Vostoke. Vladivostok: TIG DVNTS AN SSSR (in Russian).

89. Urusov, V.M., Chipizubova, M.N. (2008). Obshchie zakonomernosti geographicheskogo raspredeleniya formatsy i tipov rastitelynosti, Genezis rastitelynosti. In S.S. Gasnzey (Ed.). Geosistemy Dalynego vostoka na rubezhe XX-XXI vekov. Vol.I. Prirodnye geosistemy i ikh komponenty, Vladivostok: Dalynauka. P. 203-220 (in Russian).

90. Vasilyev, N.G., Rozenberg, V.A. (1977). Vysotnye predely rasprostraneniya drevesnoy rastitelynosti na Kurilyskih ostovah. Problemy botaniki, Vol. XIII. Baku: "ELM".P. 69-77 (in Russian).

91. Vitvitskiy, G.N. (1961). Klimat // Dalyniy Vostok. Phiziko-geographicheskaya kharakteristika. Moskva: Izd-vo AN SSSR. P. 93-117 (in Russian).

92. Vorobyev, D.P. (1963). Rastitelynosty Kurilyskih ostrovov (Vegetation of Kuril islands). Moskva-Leningrad: Izd-vo AN SSSR (in Russian).

93. Vyatkina, M.P., Gimelbrat, D.E., Golovneva, L.B., etal. (2014) Rastitelny pokrov vulkanicheskih plato Tsentralynoy Kamchatki (Klyuchevskaya gruppa vulkanov). Moskva: KMK (in Russian).

94. Whittaker, R. H. (1975). Communities and Ecosystems, New-York: Macmillan Publishing Co., Inc.

95. Wood C..A.., Kienle J.(1990). Volcanoes of North America. New York: United States and Canada.

96. Zalihanov, M.Ch., Kolomyts, E.G., Sharaya, L.S., et al. (2010). Vysokogornaya geoecologiya v modelyah. Moskva: Nauka (in Russian).

97. Zlobin, T.K, Abdurakhmanov, L.I., Zlobina LM (1997). Glubinnye seysmicheskie issledovaniya vulkana Mendeleeva na Yuzhnyh Kurilah. Tikhookeanskaya geologiya, Vol. 16, No 4.Pp. $79-87$ (in Russian).

98. Zubenok, L.I (1976). Isparenie na kontinentah. Leningrad: Gidometeoizdat (in Russian).

99. Yablokov, A.V., Yusufov, A.G. (1976).Evolutsionnoe uchenie. Moskva: Vysshaya shkola (in Russian).

Citation: Erland G. Kolomyts "Insular-Arc Volcanic Ecosystems as Centres of Forming the New Parts of Continental Biosphere(by the example of South-Kuril Insular Ridge)". American Research Journal of Earth Science; vol 1, no. 1, pp. 1-43.

Copyright (C) Erland G. Kolomyts. This is an open access article distributed under the Creative Commons Attribution License, which permits unrestricted use, distribution, and reproduction in any medium, provided the original work is properly cited. 